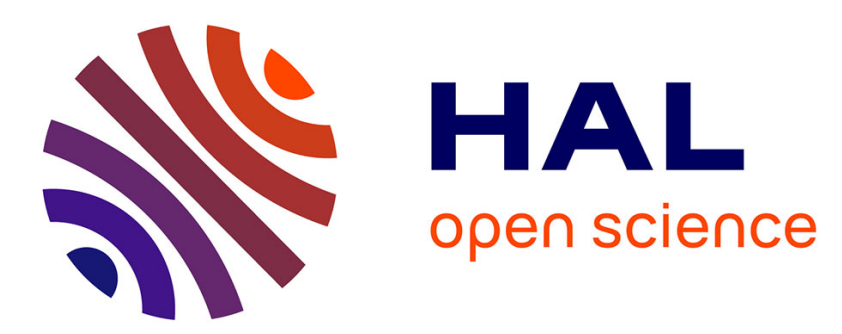

\title{
Deciphering landscape evolution with karstic networks: A Pyrenean case study
}

Amandine Sartégou, Didier L. Bourlès, Pierre-Henri Blard, Regis Braucher, Bouchaib Tibari, Laurent Zimmermann, Laëtitia Leanni, Georges Aumaitre, Karim Keddadouche

\section{To cite this version:}

Amandine Sartégou, Didier L. Bourlès, Pierre-Henri Blard, Regis Braucher, Bouchaib Tibari, et al.. Deciphering landscape evolution with karstic networks: A Pyrenean case study. Quaternary Geochronology, 2018, 43, pp.12-29. 10.1016/j.quageo.2017.09.005 . hal-01683952

\section{HAL Id: hal-01683952 https://hal.science/hal-01683952}

Submitted on 12 Oct 2020

HAL is a multi-disciplinary open access archive for the deposit and dissemination of scientific research documents, whether they are published or not. The documents may come from teaching and research institutions in France or abroad, or from public or private research centers.
L'archive ouverte pluridisciplinaire HAL, est destinée au dépôt et à la diffusion de documents scientifiques de niveau recherche, publiés ou non, émanant des établissements d'enseignement et de recherche français ou étrangers, des laboratoires publics ou privés. 
Deciphering landscape evolution with karstic networks: A

\title{
Pyrenean case study
}

Amandine Sartégou *(1,2), Didier L. Bourlès (2), Pierre-Henri Blard (3), Régis Braucher (2), Bouchaib Tibari (3), Laurent Zimmermann (3), Laëtitia Leanni (2), and ASTER Team ${ }^{+}$(2)

\begin{abstract}
(1) Université de Perpignan-Via Domitia, CNRS UMR 7194 Histoire Naturelle de l'Homme Préhistorique, 52 avenue Paul Alduy, F-66860 Perpignan Cedex, France ; (2) Aix-Marseille Université, CNRS-IRD-Collège de France, UM 34 CEREGE, Technopôle de l'Environnement ArboisMéditerranée, BP80, 13545 Aix-en-Provence, France ; (3) CRPG, UMR 7358, CNRS-Université de Lorraine, 15 rue Notre-Dame des Pauvres, 54501 Vandouvre-lès-Nancy, France
\end{abstract}

\section{${ }^{+}$Georges Aumaître, Karim Keddadouche}

*corresponding author at: Université de Perpignan - Via Domitia, UMR 7194 CNRS, 52 avenue Paul Alduy, 66860 Perpignan, France.

E-mail address: amandine.sartegou@univ-perp.fr (A. Sartégou).

\begin{abstract}
The rates and chronologies of valley incision are closely modulated by the tectonic uplift of active mountain ranges and were controlled by repeated climate changes during the Quaternary. The continental collision between the Iberian and Eurasian plates induced a double-vergence orogen, the Pyrenees, which has been considered a mature mountain range despite significant seismicity and evidence of neotectonics. Nevertheless, recent studies indicated that the range may have never reached a steady state. One option for resolving this controversy is to quantify the incision rates since the Miocene by reconstructing the vertical movement of geometric markers such as fluvial terraces. However, the few available ages for the Pyrenean terrace systems do not exceed the Middle Pleistocene. Thus, we study alluviumfilled horizontal epiphreatic passages in limestone karstic networks to increase the span of this dataset. Such landforms are used as substitutes of fluvial terraces because they represent former valley floors. These features record the transient position of former local base levels during the process of valley deepening. The Têt river valley (southern Pyrenees) is studied near the Villefranche-de-Conflent limestone gorge, where 8 cave levels have been recognized over a vertical height of $600 \mathrm{~m}$. In this setting, already published ${ }^{26} \mathrm{Al} /{ }^{10} \mathrm{Be}$ cosmogenic burial data were limited to the last $\sim 5 \mathrm{Ma}$. This work extends this initial dataset through the acquisition of cosmogenic ${ }^{10} \mathrm{Be} /{ }^{21} \mathrm{Ne}$ data, which should enable us to reconstruct a more
\end{abstract}


complete valley incision chronology. We also revise the ${ }^{26} \mathrm{Al} /{ }^{10} \mathrm{Be}$ record for the lowest portion of the valley. The obtained quantitative results are surprising relative to certain geological evidence, and the limitations of such an approach in the investigated geodynamic context are discussed. In particular, sampling within a detrital deposit (the Escaro Formation) and in the riverbeds suggests that the ${ }^{26} \mathrm{Al} /{ }^{10} \mathrm{Be}$ ratios that are associated with the lower cave levels could have been inherited by pre-burial episodes. Similarly, pre-burial catchment denudation rates that do not exceed hundreds of $\mathrm{cm} / \mathrm{ka}$ are probably tainted by the same amalgamation processes.

\section{Keywords}

Cave deposits, cosmogenic burial dating, ${ }^{26} \mathrm{Al},{ }^{10} \mathrm{Be},{ }^{21} \mathrm{Ne}$, incision rates, Pyrenees.

\section{Highlights}

- Exceptional preservation of a Neogene canyon in the eastern Pyrenees is observed, with 8 epiphreatic cave levels

- ${ }^{26} \mathrm{Al} /{ }^{10} \mathrm{Be}$ and ${ }^{10} \mathrm{Be} /{ }^{21} \mathrm{Ne}$ burial durations are obtained for intrakarstic alluvial deposits in 8 cave levels

- The post-Messinian inferred incision rates and the ${ }^{10} \mathrm{Be}$-derived denudation rates cannot be used as proxies for quantifying landscape development because of possible amalgamation processes

- The results indicate valley incision since the Burdigalian with possible pronounced fluctuations since the Messinian

\section{Introduction}

The formation and evolution of a mountain range are considered to result from both internal (tectonics) and external (climate) forcing. Numerous authors attempted to demonstrate that the climate would have a major influence on the dynamics of this antagonism at various spatial and/or temporal scales (e.g., Molnar et England, 1990; Reiners et al., 2003; Whipple et al., 2009), although this primary control is still ardently discussed (e.g., Godard et al., 2014). However, highlighting the retroactive interactions between these two forces is as complicated as comparing phenomena that occur on variable timescales. A key point to better constrain the formation and evolution of mountain ranges is to determine the distribution of the deformation and its temporal evolution. The Pyrenees, which have preserved distinct Mesozoic and Cenozoic geodynamic environments, are a unique mountain 
range within European orogens. However, our understanding of the recent geodynamic evolution of this chain remains quite fragmentary. Researchers have identified an initial phase of orogeny between $\sim 84 \mathrm{Ma}$ and $\sim 65 \mathrm{Ma}$, followed by a potential quiescence phase up to 59 Ma long that predated a recovery in orogenesis (Ford et al., 2015). Furthermore, the eastern section of the chain could never have reached a steady state. Despite the improvement in observational techniques over the past decade and the acquisition of numerous thermochronological data (e.g., Fitzgerald et al., 1999, Maurel et al., 2008, Vacherat et al, 2016), supplementary data are still required to constrain the recent evolution (last $20 \mathrm{Ma}$ ) of the chain. As an example, the origin of the flat surfaces at high altitudes (e.g., Babault et al., 2005; Calvet and Gunnell, 2008; Bosch et al., 2016; see Supp. Info) and their significance with regard to a potential post-orogenic uprising is still debated, these paleo-surfaces being (deeply) incised (e.g., Ortuño et al., 2013; Monod et al., 2016; Mouchené et al., 2017). Another critical point is the high microseismicity of the chain, which is quite incompatible with a moderate potential activity (e.g., Chevrot et al., 2011). In addition, recent work on the Lannemezan mega-cone showed that intense Mio-Pliocene tectonic activity is not required to form this mega-structure (Mouchené et al., 2017).

One option for resolving this controversy is to quantify the incision rates since the Miocene by reconstructing the vertical movement of geometric markers, such as fluvial terraces. However, the few available ages for the Pyrenean terrace systems do not exceed the end of the Lower Pleistocene (e.g., Stange et al., 2013; Delmas et al., 2015). Moreover, alluvial terraces are poorly preserved in some valleys. Thus, we study alluvium-filled horizontal epiphreatic passages in limestone karstic networks to increase the time span of this dataset. Such landforms are used as substitutes of fluvial terraces because they represent former valley floors (e.g., Palmer, 2007; Audra et al., 2013). These features record the transient position of former local base levels during the process of valley deepening. Until now, only relative dating based on correlations between staged levels and external terraces have been conducted on caves in the study area. However, establishing the absolute chronology of a cave's genesis remains rather complex, even if the absolute dating of the trapping of alluvium in caves with the cosmogenic burial dating method may be relevant in this case (e.g., Granger et al, 1997; Häuselmann et al., 2005; Tassy et al., 2013). The classical cosmogenic nuclide chronometer for this task is the combination of in situ-produced ${ }^{26} \mathrm{Al}$ and

${ }^{10} \mathrm{Be}$ cosmogenic nuclides that are measured in quartz, which cover the 0.2-6 Ma period. A preliminary study of two stepped systems in the Têt river valley was led by Calvet et al. (2015). The obtained burial durations yielded a mean incision rate of $\sim 55 \mathrm{~m} / \mathrm{Ma}$ since the Zanclean (5.3 - 3.6 Ma), which increased to $92 \mathrm{~m} / \mathrm{Ma}$ during the Quaternary. These authors also established that pre-burial catchment denudation rates ranged from 35 to $7 \mathrm{~m} / \mathrm{Ma}$, with an 
increase during the Early Quaternary. Nevertheless, this method has several limitations: notably, the ${ }^{26} \mathrm{Al}-{ }^{10} \mathrm{Be}$ couple cannot be used to date objects older than $6 \mathrm{Ma}$ because of their respective half-lives $\left({ }^{26} \mathrm{Al}:(0.717 \pm 0.024) \mathrm{Ma} ;{ }^{10} \mathrm{Be}:(1.387 \pm 0.012) \mathrm{Ma}\right)$ alongside the sensitivity of the accelerator mass spectrometry technique. To overcome this limitation, one solution involves analyzing the concentration in the stable nuclide ${ }^{21} \mathrm{Ne}$ within the same mineral to obtain the ${ }^{21} \mathrm{Ne}_{-}{ }^{10} \mathrm{Be}$ burial durations (e.g., Balco and Shuster, 2009; McPhilipps et al., 2016).

Considering the promising results from this initial study (Calvet et al., 2015), we decided to complete the dataset and densify the sampling in the already studied cavities. For this purpose, eight levels in the Têt river catchment, which is one of the easternmost valleys of the Pyrenees, were explored. We surveyed fifteen horizontal caves and collected alluvial deposits in eleven of them to measure their cosmogenic nuclide concentrations $\left({ }^{10} \mathrm{Be},{ }^{26} \mathrm{Al}\right.$ and/or ${ }^{21} \mathrm{Ne}$ ). We also re-analyzed the samples that were measured by Calvet et al. (2015) and additional samples from the same caves. The quantitative data that were acquired and presented in this paper reveal inconsistencies with some of the geological observations, so the methodology will be questioned through the investigation of potential non-visible effects, such as particle sizes and lithology disparities. The basic methodology, including the need to consider that the burial durations and/or paleo-denudation rates are calculated from TCN concentrations averaged from an amalgams of quartz grains taken from sedimentary deposits, is also questioned. Methodological cross-checking between the ${ }^{21} \mathrm{Ne}-{ }^{10} \mathrm{Be}$ and ${ }^{26} \mathrm{Al}-{ }^{10} \mathrm{Be}$ cosmogenic pairs have thus been conducted when possible for a better understanding of the related impacts of these parameters. Finally, the obtained scattered paleo-denudation rates and the limitations of such an approach in the Pyrenean geodynamic context are discussed.

\section{Geological and geodynamical contexts}

\subsection{Lithological and structural contexts of the eastern Pyrenees}

The Pyrenees are a mountain range in southwestern Europe. This mountain range, which forms a $400 \mathrm{~km}$-long geographical barrier of $\mathrm{N} 110^{\circ}$-orientation and had developed along the boundary between the Iberia and European plates (Choukroune, 1992), is the result of the Late Cretaceous-Cenozoic inversion of a Cretaceous transcurrent hyper-extended rift that was created during the opening of the Bay of Biscay (Lagabrielle et al., 2010). The structures continue along the southern shore of the Bay of Biscay to the Asturias to the west, which extends this chain to $600 \mathrm{~km}$.

The axial zone of the Pyrenees consists of various terrains of Precambrian and 
$295 \mathrm{Ma}$; Engel, 1984). The studied catchment area (Figure 1) includes the Puigmal-Canigou,

143 Carlit and Madrès massifs. The axis of the Madrès massif consists of the WNW-ESE syncline

144 of Villefranche-de-Conflent (Guitard et al., 1998), which is a stack of Hercynian late-folded

145 syncline foliage that affected the sedimentary or slightly metamorphosed formations from the

146 Middle and Upper Paleozoic. The base of the valley has massive outcrops of Devonian and

147 Carboniferous limestones and dolomites. Towards the top of the stratigraphic series (Silurian

148 - Upper Ordovician and Lower Carboniferous - Visean), pelites, calcschists, argillites and

149 sandstone schists, which are generally less resistant to erosion because of their laminated

150 structure, are predominant. Two thick sets of Ordovician, Cambrian and probably

151 Precambrian schistose rocks flank this axis. These various petrographic formations (pelitic,

152 schistous, marble, microconglomeratic and volcanodetritic facies) form the Canaveilles

153 (Laumonier et al., 1996, 2015) and Jujols series from the base to the summit (Laumonier et

154 al., 1996, 2015). These rocks are intruded by Ordovician granite plutons.

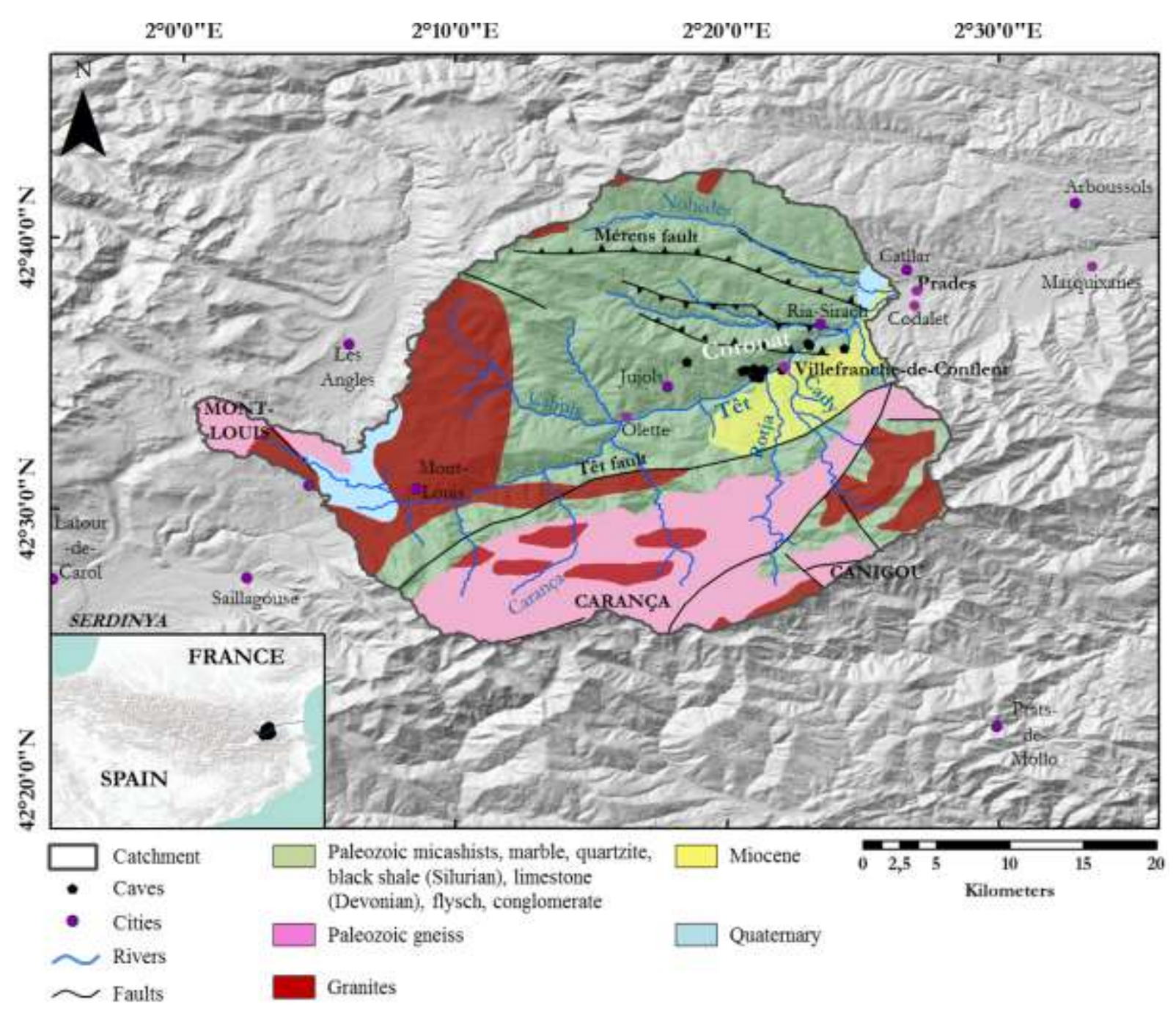

156 Figure 1 : Lithostructural features of the Têt catchment (according to IGME - BRGM data). Alluvial

157 sediments that were trapped in karstic networks originated from Paleozoic crystalline massifs (gneiss, 158 granites), metasediments and supposed Miocene deposits from the Escaro Formation because of the 
Around 20-25 Ma ago, collision-related deformation in the central and eastern Pyrenees ceased, the crustal deformation resulting from the convergence between the Iberia and European plates being then accommodated by the Betic Cordillera (Vergés et al., 2002). After the collision or during the last phase of plate convergence, while the central and western Pyrenees remained under a compressive regime, the eastern Pyrenees were affected by a period of crustal thinning that was related to the well-defined Oligocene-Early Miocene rifting that affected the Gulf of Lions (e.g., Ortuño et al., 2013). During the Lower Miocene (21-15 Ma), the eastern Pyrenean domain collapsed and was then divided into grabens that were filled with thick detrital sedimentary series (Guitard et al., 1998 and references therein). These features in the Roussillon and Conflent basins, the Escaro and Col de Fins formations, are estimated to have been deposited during the Lower Miocene (Figure 1; Supp. Info). These are fluviatile formations, composed of clasts coming from the Têt River high valley and the surrounding massifs such as the Canigou massif. This succession of collapse events followed by filling phases towards the Early Miocene has sometimes been called into question.

Then, the closure of the strait between the Atlantic Ocean and the Mediterranean Sea at the end of the Miocene ( 5.9 Ma; Gautier et al., 1994; Suc et al., 1994) leaded to a drop of $1500 \mathrm{~m}$ of the base level (Hsü et al., 1973) which broke the eustatic equilibrium. This event, called the Messinian Salinity Crisis (MSC), induced a major incision of the periMediterranean pre-MSC drainage systems (e.g., Hsü et al., 1973; Clauzon, 1982). Very deep canyons were then dug. Some vestiges of Pliocene detrital deposits filling these canyons (e.g. Depéret, 1895) as well as the upstream propagation of the incision, depicted by knickpoint migration, have been studied (e.g., Loget and Van Den Driessche, 2009). The morphology of the canyons is a priori indeed well preserved because of the sudden rise of the base level $(+80$ $\mathrm{m}$ from the current level) and of the concomitant deposition of sediments in Gilbert deltas which reduced the rivers erosive power (e.g., Clauzon et al., 1995; Loget et al., 2006). Opinions differ as to whether the Têt River valley, particularly the Conflent area, is a Messinian paleo-canyon. The history of the Upper Miocene and of the Messinian evolution of the Conflent Basin is still debated. It is currently accepted that deposits of the late Miocene, the Col de Fins Formation, which is consisting of fluvial facies and quartzite blocks, would be present west of the basin. This deposit would have been largely denuded in response to the MSC, leaving only a few scraps. Upper Pliocene formations are dominated by fluvial arkosic sands and conglomerates. These 
detrital sedimentary series were partially removed and remobilized by river downcutting during the Upper Pliocene and Pleistocene. Staircased alluvial terraces that range from 20 to $200 \mathrm{~m}$ above the present-day thalweg support this incision. Based on current weathering profiles (Calvet, 1996), cartographic relationships (Delcaillau et al., 2004), and heavy mineral contents (Debals, 2000), the chronology of this fluvial downcutting still requires absolute dating to be better constrained. In this area, the Quaternary superficial formations are represented by the high terraces to the SE of Ria (Calvet et al., 2015). The lower terraces occupy a large portion of the Têt valley between Serdinya and Prades. Their location and their relationship to karstic networks are described in Hez et al. (2015). Alluvial terraces into the Villefranche-de-Conflent gorges are poorly preserved. The T1 terrace $(\sim+20 \mathrm{~m})$ is continuous and well-represented. The T2 terrace $(25-30 \mathrm{~m})$ is poorly represented in the gorges and poorly conserved. Within the gorges, the T3 and T4 levels are absent. Altimetric correlations between terraces and cavity levels have been proposed (Calvet et al., 2015, Hez et al., 2015). However, in addition to the fact that the absolute age of the alluvial terraces is poorly constrained, a convincing correspondence remains to be established through notably classical petrological and mineralogical studies and through geochemical characterizations of the source of the material.

The study area is drained to a local base level by the Têt and its main tributaries. The Têt is a river that is connected to the Mediterranean domain. This river originates at an altitude of $2405 \mathrm{~m}$ in the Carlit massif, pours towards the southeast as it crosses the crystalline massif of Mount-Louis, and then changes direction at Fontpédrouse to flow towards the northeast - southwest along the plane of the Conflent graben (Figure 1). The Cady and the Rotja, which are tributaries along the right bank of the Têt, drain augen orthogneiss and biotite granites, which are represented on most of the Canigou massif. Most of the drainage is confined to canyons with a flat alluvial floor, but a portion of the river or its tributaries seems to be systematically lost over time in the carbonate massifs (Figure 1).

\subsection{Karst features and cave systems}

The confined karst of Villefranche develops in the Devonian carbonate rocks in the eastern portion of the syncline. This geological unit is characterized by metamorphic limestones and some marbles (Guitard et al., 1998). The syncline extends from west to east over approximately thirty kilometers, with a width of approximately $4 \mathrm{~km}$ on its eastern section, where the karstification is most important. The Hercynian major fault of Mérens borders the northern Coronat massif (Figure 1) and confines the karst in the Têt river valley. The Hercynian orogeny would be responsible of the main structuration of the massif. Paleogene compression, which deforms the already folded Paleozoic terrains, has probably 

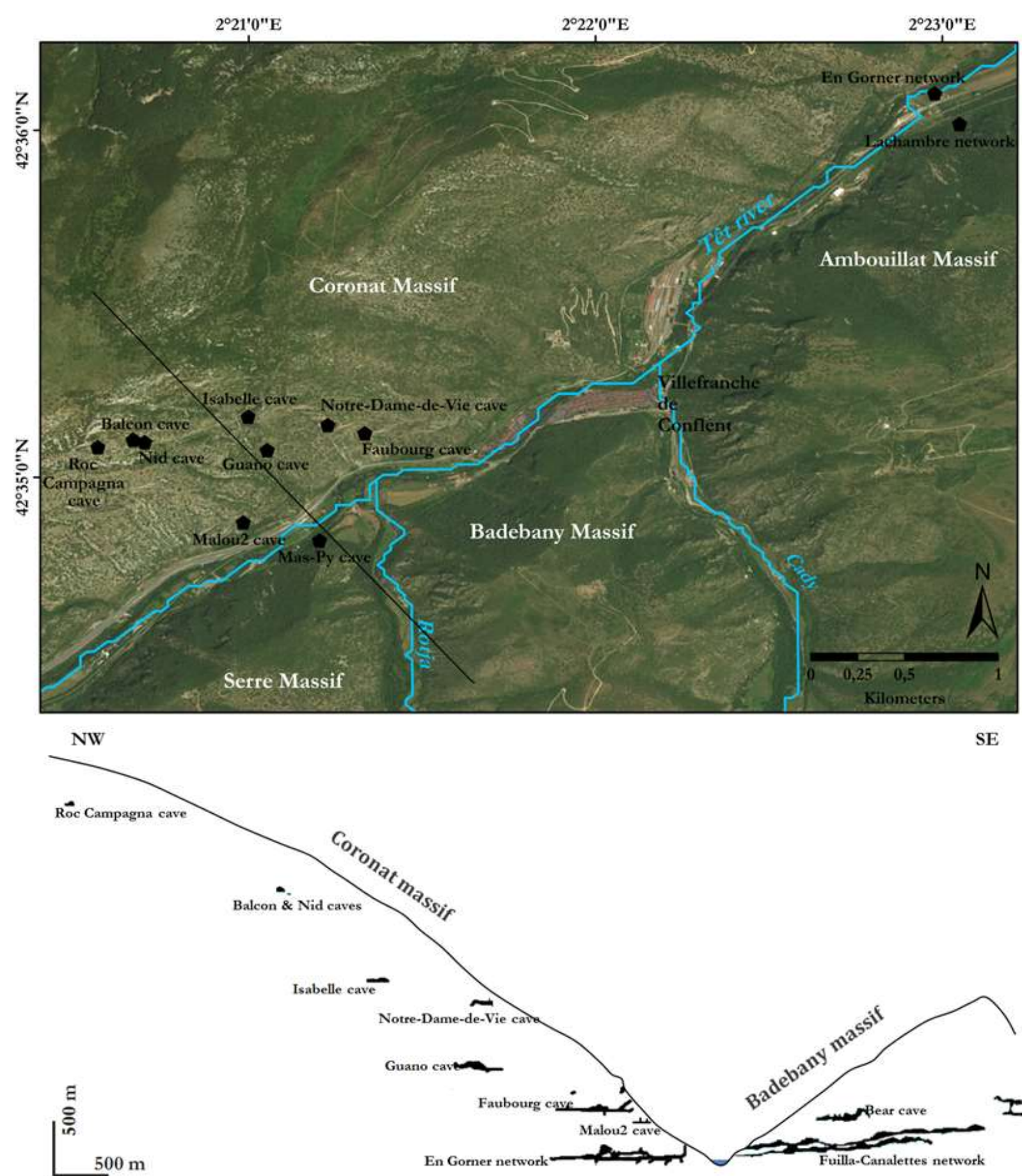

Figure 2: Map and projected section (modified after Calvet et al., 2015) of the Têt River valley near Villefranche-de-Conflent, which shows the karstic network's spatial distribution and patterns in the massifs. Eight epiphreatic levels are clearly identifiable at the massifs of

Badebany (right bank) and Coronat (left bank) and have been investigated. Their establishment is influenced by the Têt and its tributaries, the Cady and the Rotja. The floors close to the current base level are the most developed. The perched levels have probably been trimmed because of the removal of the flanks of the massif over time.

Few surface karst features are present in this area, and most of the networks are 240 horizontal. If wells, cascades or potholes were present, they disappeared because of the 
backwards slopes or erosion. However, underground karst features are well developed in four

main massifs (Coronat in the left bank, Serre, Badebany and Ambouillat in the right bank), which were largely described by Calvet et al. (2015).

We can distinguish eight epiphreatic levels at $~ 600$-m height on a valley transect near Villefranche-de-Conflent (Figure 2; Calvet et al., 2015; Hez et al., 2015). This study area is therefore very original and complex because of the high density of levels in this area, even if this fact is quite classical in the Pyrenees. The first level, which is close to the current base level of the Têt River, corresponds to the large underground networks of the karst of Villefranche. This level is particularly developed, with $\sim 75 \mathrm{~km}$ of galleries discovered (En Gorner, Lachambre and Fuilla - Canalettes networks), probably because of a pronounced base-level stationary phase (Audra, 1994). The seven epiphreatic levels above the large karstic systems retain only limited sections of galleries under development because of (i) erosion, which led to the retreat of the southern slope of the massif, thus reducing the size of the horizontal duct; (ii) the total clogging of galleries by gravitational deposits, concretions, and detrital deposits, preventing any speleological exploration towards the logical sequence; and (iii) sudden interruptions of galleries because of faults or fractures, disconnecting the conduits by shifting the blocks of the massif, as observed in the caves of Faubourg and NotreDame-de-Vie (Calvet et al., 2015; Hez et al., 2015).

One of the crucial points of this area is the rarely observed inter-connections of subhorizontal cavities (Hez, 2015; Hez et al., 2015). Indeed, unlike a staggered network, whose levels are inter-connected by vertical wells, the staging of cavities in the Villefranche karst seems to consist of distinct sub-horizontal networks from repeated base-level fluctuations in the Têt River.

Erosion morphologies provide valuable information on previous underground circulations, including the direction of the flows. The waves of erosion that were observed on the walls of the staging cavities support their functioning towards the interior of the massif in the direction of the axis of the Villefranche syncline (Faubourg cave) and parallel to the Têt River (SO-NE), as in the Guano cave and in a majority of the En Gorner network (Hez, 2015; Hez et al., 2015). These stretches of staged epiphreatic levels can therefore correspond to successive self-capture levels of the Têt on the left bank. On the right bank, cavity staging is limited to two or even three levels in the massif, significantly lower than those in the Coronat massif (Figure 2).

\section{Methods}

\subsection{Sampling strategy}




\subsubsection{Cave sediments}

The use of karst as a paleoenvironmental marker and the study of karstic infillings are particularly interesting because karst is a conservative environment in which alluvial sediments are protected from denudation. Sediments are transported to galleries by interrupted streams or stream piracy from an epigeous river, and their analysis enables us to determine their surface origin and their mode of deposition. In addition, karst records the position of the bottom of the valley at some point. Epiphreatic galleries indicate water-table proximity. During valley deepening, various levels of horizontal conduits are generated, with recent networks forming below previously abandoned generations. However, the opposite is also possible during base-level rise (Mocochain et al., 2009; Tassy et al., 2013). Thus, staged karstic systems record the transient positions of previous local base levels, similar to fluvial terraces during valley deepening. The shape of the galleries and the morphologies on the walls describe the modalities of the digging, filling and draining of the galleries (Figure 3a). In any case, the duration of the development of these networks is supposed to be negligible relative to the duration of the processes that are quantified in this work. However, the scale transfer from the average burial duration that is recorded by the analyzed quartz grains to the "age" of the sedimentary deposit that contained them is far from straightforward, as is the subsequent deduction of the "age" of the gallery where the sampling occurred and, a fortiori, the "age" of the network. Moreover, the basic assumption that a single burial age can be extrapolated to the entire sedimentary sequence in the same network is not straightforward, which supports collecting several samples along the same unit to have a constant burial age. Furthermore, we must face ill-defined conceptual principles, such as the notion of the formed network. Is a network considered to have been formed when it loses its active karst status and becomes a paleokarst, or is it still in formation when climatic or eustatic processes cause the reuse of its conducts? Moreover, to our knowledge, no studies exist that quantify the required time to form a cavity or a network through pertinent absolute dating, the estimates being essentially based on dissolution and structural criteria. In addition, if these studies exist, such studies would only be relevant in their particular context, with the network formation duration greatly depending on the geological, tectonic, climatic, and eustatic contexts of a given region during the investigated period.

To estimate the incision rate of the main river, the morphology of each gallery was analyzed and the alluvium that was trapped and preserved in these horizontal passages was sampled for absolute dating (Figure 3b, c, d). 
312 have been thoroughly described by Calvet et al. (2015).

\begin{tabular}{|c|c|c|c|c|c|c|}
\hline Caves & $\begin{array}{c}\text { Samples } \\
\text { ID }\end{array}$ & $\begin{array}{c}\text { Latitude } \\
\left({ }^{\circ}\right)\end{array}$ & $\begin{array}{c}\text { Longitude } \\
(\mathbf{(})\end{array}$ & $\begin{array}{c}\text { Elevation } \\
(\mathbf{m})\end{array}$ & $\begin{array}{c}\text { Relative } \\
\text { elevation } \\
(\mathbf{m})\end{array}$ & $\begin{array}{c}\text { Development } \\
(\mathbf{m})\end{array}$ \\
\hline Puits des Racines & PDR & n.c. & n.c. & 443 & 8 & 17600 \\
\hline Lachambre & AM & 42.600306 & 2.384164 & 455 & 20 & 26000 \\
\hline Mas-Py & MP & 42.580303 & 2.353403 & 486 & 20 & 100 \\
\hline Malou-2 & MA2 & 42.581167 & 2.349739 & 501 & 43 & 100 \\
\hline Ours & OU & 42.585528 & 2.367028 & 515 & 57 & 552 \\
\hline Sirach & SI & 42.598639 & 2.405250 & 487 & 100 & 1350 \\
\hline Faubourg & F & 42.585447 & 2.355583 & 545 & 110 & 485 \\
\hline Guano & GU & 42.584639 & 2.350889 & 600 & 180 & 250 \\
\hline Notre-Dame-de-Vie & NDV & 42.585846 & 2.353801 & 710 & 275 & 60 \\
\hline Balcon & BA & 42.585139 & 2.344447 & 907 & 500 & 5 \\
\hline Nid & NID & 42.585019 & 2.345003 & 914 & 500 & 14 \\
\hline Roc Campagna & CAM & 42.584778 & 2.342750 & 1050 & 580 & 30 \\
\hline Roquefumade & RF & 42.590344 & 2.308719 & 1358 & 836 & 120 \\
\hline
\end{tabular}

Table 1: Location of the sampled cavities. The provided altitude is that of the current entrance of the cavities. These levels are horizontal, and the altitude of the paleo-drain varies by only a few meters. The relative altitude is that calculated by projection on a perpendicular plane to the current course of the Têt, ignoring its past shifting. The developments of the cavities are those that are known through current speleological exploration. The coordinates of En Gorner's network entrance cannot be transmitted. The point is placed close on the map of Figure 2, but not at the exact location.

The Lachambre network (+ $20 \mathrm{~m}$; Table 1$)$ is located on the right bank. This network consists of two main galleries that are parallel to the Têt (SW-NE) and intersected by meanders because of SE-NW fractures. Numerous morphologies of fluvial erosion and alluvial deposits (Figure 3c), including large concretions that are marked by scallops, are observed. Notches are visible on the walls of the large ducts, marking the passage of an underground river. The Sirach cave could indicate the paleo-emergence of a higher level to the Lachambre network (Hez, 2015). This atypical cavity largely develops in a Burdigalian limestone tectonic breccia. The Mas Py cave was probably a leakage of the Rotja River that emerged in the Têt valley.

The En Gorner network (+8 m; Table 1) is a major cavity in the Coronat Massif that was partially traversed by a river, in which two floors can be discriminated. This network is close to the current level of the Têt. The ducts are mainly oriented SO-NE. These ducts are 331 large (Figure 3a) and exhibit many collapses and highly concretionary areas. Some galleries may still experience water rise during snowmelt periods or prolonged episodes of heavy precipitation. In this case, the downstream siphon of the underground river saturates and

334 returns the unabsorbed quantity to the upper galleries. Leakages of the neighboring Nohèdes 335 valley also could have poured water into and shaped the network (Hez, 2015). 

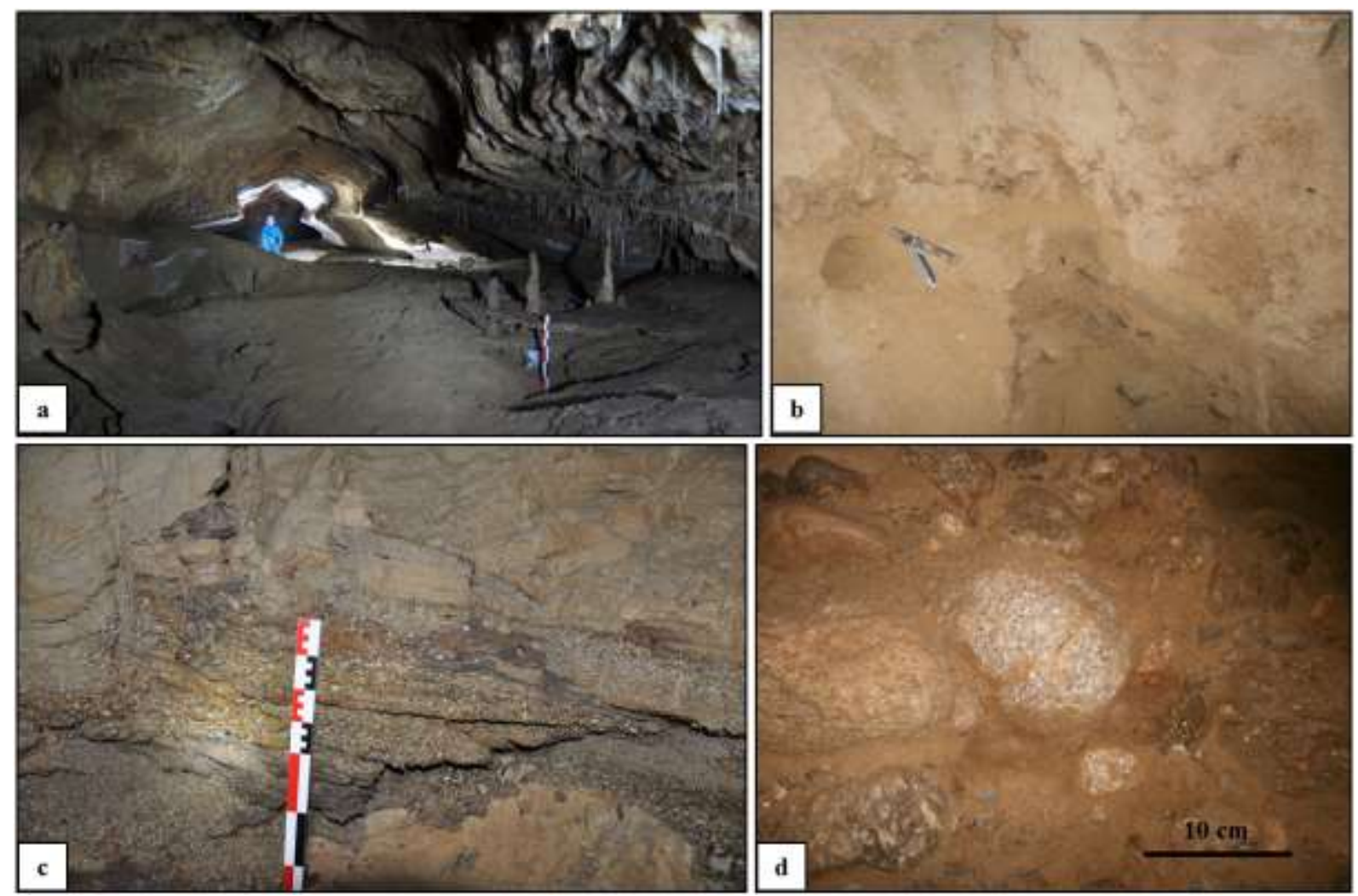

Figure 3: a) Porte de Fer gallery (En Gorner's network), PDR2 sampling site. The morphology of this section is characteristic of the recorded paragenetic regime in the network (Hez, 2015; Hez et al., 2015). The calcite floor, which is visible in the foreground, seals fine deposits. Sand filling partially covers this carbonate deposit. A more recent generation of concretions sporadically seals the deposit. b) PDR7 sampling site in the Sablier (En Gorner's network). The sandy bench is located above the picked pebbles (PDR8 to PDR13). c) AM2 sampling site. Sandy-bedded deposits in the Lachambre network are surmounted by laminated clay loams, indicating a prolonged episode of paragenetism. d) PDR5 to PDR13 sampling sites. Granites and gneiss pebbles in the En Gorner's network. The deposit is massive and clogs the Sablier gallery.

Villefranche karst have variable particle sizes and are found in the form of clay, silt, sand (Figure 3b, c), gravel and pebble (Figure 3d). These detrital fillings were brought by a paleoTêt and its tributaries (mainly Cady and Rotja) and were conserved in the endokarst at almost all levels of the tier. We sampled amalgams among the few available deposits, provided that we could rely on the classic markers of phreatic and epiphreatic circulation, the geometry of the deposits, and the selected deposit was an alluvial deposit and not an intrakarstic deposit. These deposits consisted of gneiss, granitoid, quartzite, micaceous sands, schist, and micashist at almost all levels of staging. Considering the lithologies in the Têt watershed, the Têt and its tributaries were likely responsible for the transport and deposition of these trapped alluvial 
deposits in the cavities of the Villefranche karst. The lithologies and particle sizes within each cavity are detailed in Table 4.

362

363

364

\subsubsection{Riverbeds}

To constrain the current denudation rates and concentration ratios, we sampled sediments that were transported by the main active rivers (Figure 4; Table 2), with sand and pebbles being treated separately for comparison.

Such sampling was also conducted to analyze the potential effects on the concentration ratios of the collected sediments from alluvial deposits that were remobilized by the rivers before being deposited in the cavities, even if extrapolating the current results to the prospected cavity deposits is inappropriate because of likely different hydrological conditions. Thus, a modern sediment sample was taken upstream of these deposits at Thuès-entre-Valls to detect possible interference from the cosmogenic signal from the Escaro Formation (TT point; Figure 4d).

\begin{tabular}{|c|c|c|c|c|}
\hline Location & $\begin{array}{c}\text { Samples } \\
\text { ID }\end{array}$ & $\begin{array}{c}\text { Latitude } \\
\left({ }^{\circ}\right)\end{array}$ & $\begin{array}{c}\text { Longitude } \\
\left(^{\circ}\right)\end{array}$ & $\begin{array}{c}\text { Elevation } \\
\text { (m) }\end{array}$ \\
\hline Têt-Villefranche & TV & 42.585722 & 2.363639 & 456 \\
\hline Têt-Thuès & $\mathrm{TT}$ & 42.525000 & 2.226750 & 806 \\
\hline Rotja - Fulla & RO & 42.578806 & 2.355861 & 494 \\
\hline Cady - Canalettes & CAD & 42.581694 & 2.371055 & 451 \\
\hline
\end{tabular}

Table 2: Location and elevation of the four riverbed sediment sampling sites in Figure 4.

When possible, we distinguished the lithologies. Certain infrastructures are present upstream of the course of the Têt, especially the Bouillouses dam, which was built between 1903 and 1910. Development works have also been conducted along the Rotja River in recent decades. Fortunately, most drains in the watershed do not pass through this point. Moreover, the measurements of cosmogenic nuclide concentrations in modern river samples in different drainage basins enable us to calculate the local catchment-integrated production rates for ${ }^{26} \mathrm{Al}$ and ${ }^{10} \mathrm{Be}$. The use of present-day rivers to determine the past production rate is correct assuming a constant denudation rate and stable altitude for the riverbed.

Given their actual drainage networks, the Cady and the Rotja Rivers may have incised the Neogene Escaro Formation (see Supp. Info) and transported embedded sediments, which were included in their bed loads. We must verify such a hypothesis because pebbles that were transported by these tributaries may have been deposited in the studied cavities of the Badebany and Serre massifs. The other massifs in the area, whose drains could potentially feed the Têt, must also be considered. Additionally, we must examine whether this potential influence was attenuated in sands. A much larger number of grains can be analyzed in a sand sample (compared to pebble samples), so sands may more accurately represent the 
concentrations of the erosion products of these two sub-watersheds. Therefore, sediments were collected both before the confluence between the Rotja and the Têt, specifically, at the RO point, and after their confluence at the TV point (Figure 4c). The TV point is $1.3 \mathrm{~km}$ downstream of the RO point. Finally, we sampled the Cady before its confluence with the Têt (Figure 4b) at the CAD point. At these last three locations, we distinguished the particle sizes and lithologies. We could not collect riverbed sediments after the confluence between the Têt and the Cady because of accessibility issues.

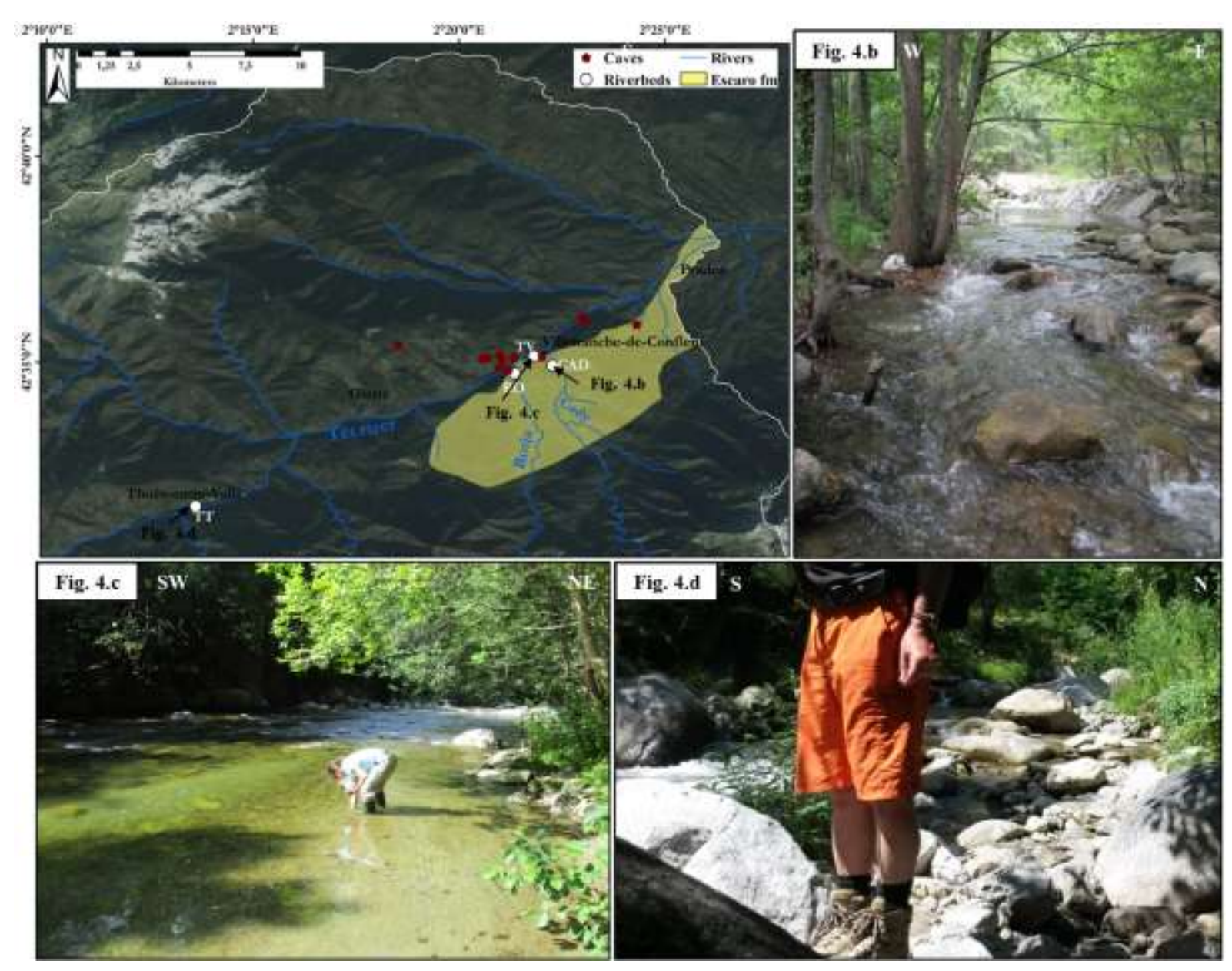

Figure 4: Details of the riverbed sediment sampling sites. The locations are given in Table 2. Pictures were taken during low-water periods. a) Map that shows the four sampling locations (white dots) and their relationships with both the Miocene Escaro Formation (in yellow) and cave entrances (red dots). b) Cady sampling site. The riverbed is 5-7 $\mathrm{m}$ wide and contains metric blocks. The flow is torrential, and particle sizes smaller than coarse sands were absent, even on the banks. c) Villefranche-deConflent sampling site on the Têt river. The particle sizes range from fine sands on the banks to metric blocks within the bed of the river. d) Thuès-entre-Valls sampling site. The riverbed's width does not exceed five meters, and the flow is torrential. At this point, the river flows on steeper slopes. Particle sizes smaller than coarse sands were absent, even on the banks. 
burial/re-exposure histories of its components (Table 3). While some authors assigned a Miocene age to the Escaro Formation (Guitard et al. (1998) and references therein), other authors assumed this formation as being a component of a late Pliocene set (e.g., Clauzon et al., 2015 and references therein). Solving this controversy is beyond the scope of this study. The samples were collected from a quarry that was exploited at the beginning of the last century for hematite and fluorite. According to the aforementioned authors, it should be pointed out that this quarry may equally well be found in the Escaro Formation as in a gneissic thrust slice of the olistoliths. In the end, it does not matter, some of these slices being intercalated in the Escaro Formation (e.g., Oele et al., 1963). In the western area of the basin between Prades and Escaro, the yellowish formation consists of an alternation of very poorly sorted quartz-feldspathic sands and essentially gneissic metric-sized block levels (Guitard et al., 1998). The predominance of gneiss indicates that the Canigou massif is the main source of the clasts, which is reasonable because of the large exhumation of the massif in response to the opening of the Gulf of Lion (Maurel et al., 2008). The base of the formation has a large dip of approximately $30^{\circ}$ towards the N-NE at the outcrop (Figure 5). This formation's thickness, which is at least $600 \mathrm{~m}$, can be estimated north of Escaro. The degrees of alteration vary. It is worth noting that there is apparently no paleosoils within the Escaro formation. EB1, EB2 and EB3 from the base of the formation to distinguish particle sizes and lithologies. The same protocol was applied to one of the samples (ET1, ET2 and ET3) from the mid-slope bench, which enabled us to quantify the accumulation rates.

\begin{tabular}{|c|c|c|c|c|}
\hline Location & $\begin{array}{c}\text { Samples } \\
\text { ID }\end{array}$ & $\begin{array}{c}\text { Latitude } \\
\left({ }^{\circ}\right)\end{array}$ & $\begin{array}{c}\text { Longitude } \\
\left({ }^{\circ}\right)\end{array}$ & $\begin{array}{c}\text { Elevation } \\
(\mathbf{m})\end{array}$ \\
\hline Escaro quarry - halfway up bench & ET & 42.543278 & 2.313500 & 926 \\
\hline $\begin{array}{c}\text { Escaro quarry - base of the } \\
\text { formation }\end{array}$ & EB & 42.542972 & 2.308694 & 951 \\
\hline
\end{tabular}



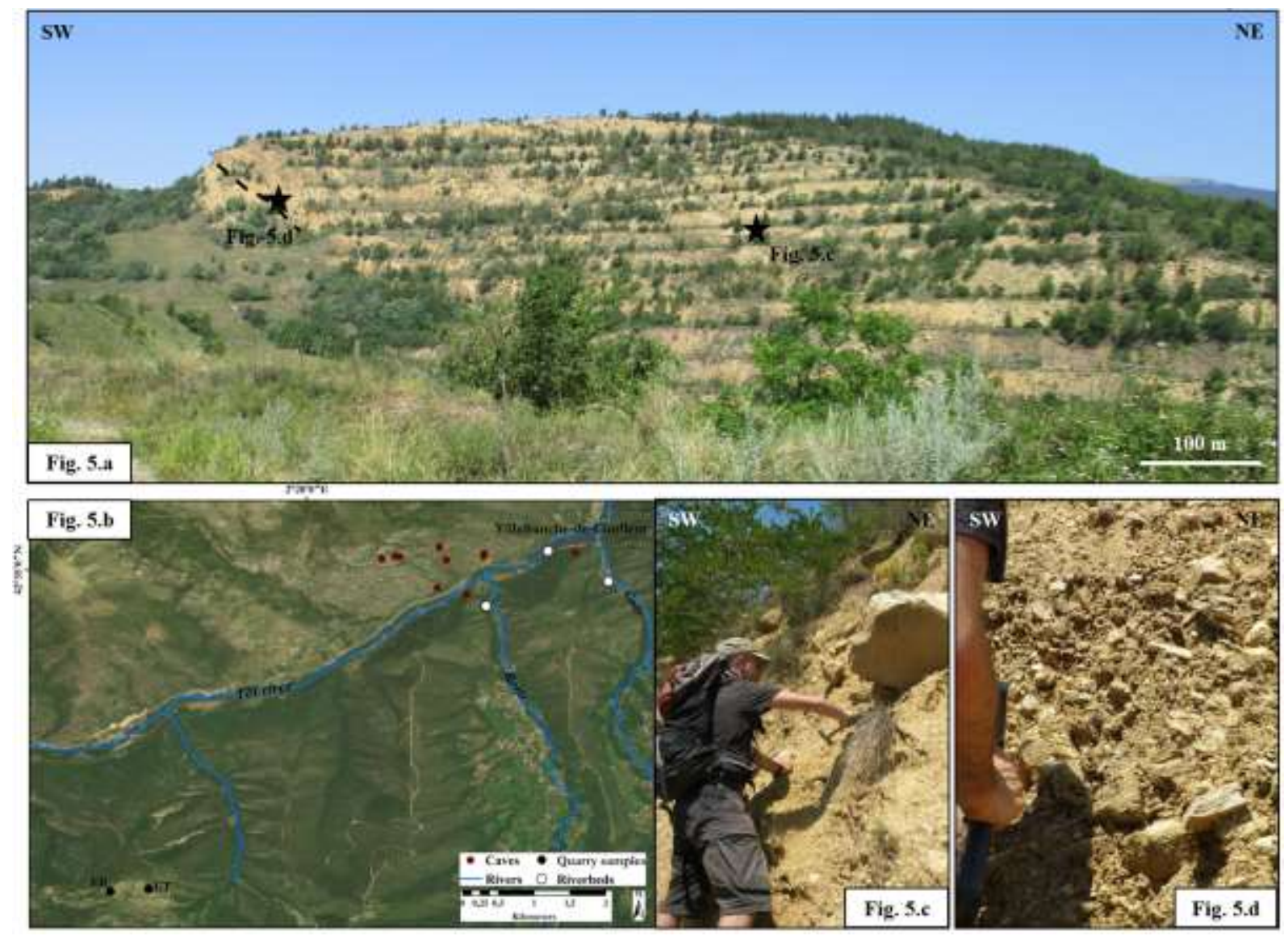

Figure 5 : Escaro quarry site. The locations are given in Table 3. a) Panorama of the quarry that was exploited during the 20th century. The re-exposure period is negligible, and the selected sites are properly shed under more than $30 \mathrm{~m}$ of sediment. The base of the supposed Miocene formation is plotted with a dip of $30^{\circ}$ to the NNE. b) Map that shows the two sampling locations (black dots) and their relationships with both the three riverbed sampling sites (white dots) and cave entrances (red dots). EB represents the base of the formation samples and ET the halfway-up crossing samples. c)

Halfway-up bench-sampling site. The particle sizes range from medium sands to gneiss metric blocks.

d) Base of the formation sampling site, which is mainly sandy deposits and clasts of gneiss and quartzites.

\subsection{Burial duration determination systematics}

The burial dating method is based on the differential radioactive decay of two cosmogenic nuclides, which accumulate in quartz minerals of surface rocks that are exposed to cosmic rays. At a depth of 8-10 m, in situ-production from neutrons is stopped, and muons represent only $1 \%$ of the total surface production, so the significant burial of the sample of interest halts the in situ production of cosmogenic nuclides. The concentrations of initially accumulated radionuclides $\left({ }^{26} \mathrm{Al}\right.$ and $\left.{ }^{10} \mathrm{Be}\right)$ then decrease as a function of their respective half-

452 lives. Knowing the production ratio of the cosmogenic nuclides of interest in quartz minerals, 453 enables us to determine their burial age and the maximum denudation rates that prevailed in 454 the source area before the samples were buried by measuring the ${ }^{26} \mathrm{Al} /{ }^{10} \mathrm{Be}$ and $/$ or ${ }^{10} \mathrm{Be} /{ }^{21} \mathrm{Ne}$ ratios in the samples. 
of the caves that were sampled in this study are always overlain by more than $30 \mathrm{~m}$ of rocky material in all directions, therefore making post-burial production negligible. The accuracy of the results $\left({ }^{26} \mathrm{Al} /{ }^{10} \mathrm{Be}=\mathrm{R}_{\mathrm{AB}}\right)$ relies on the following assumptions: (i) the quartz from which the TCN are extracted was exposed long enough at the surface to accumulate measurable concentrations of cosmogenic radionuclides; (ii) the transport time before burial was negligible compared to the exposure duration to cosmic rays on a surface under a denudation regime, so the storage duration within the catchment was limited; and (iii) burial was rapid and deep enough to avoid cosmogenic nuclide post-burial production.

\subsection{1. ${ }^{26} \mathrm{Al} /{ }^{10} \mathrm{Be}$ based burial duration determination}

A rock that is exposed to cosmic radiation accumulates terrestrial cosmogenic nuclides (TCN) such as ${ }^{26} \mathrm{Al}$ and ${ }^{10} \mathrm{Be}$, whose concentrations can be calculated by using the following equation (Braucher et al., 2011):

$C(x, \varepsilon, t)=$

$\mathrm{C}\left(\mathrm{x}, \varepsilon^{\prime}, \mathrm{t}^{\prime}\right) \exp (-\lambda \mathrm{t})+\frac{\mathrm{P}_{\mathrm{sp}} \cdot \exp \left(-\frac{\mathrm{x}}{\mathrm{L}_{\mathrm{n}}}\right)\left(1-\exp \left(-\mathrm{t}\left(\frac{\varepsilon}{\mathrm{L}_{\mathrm{n}}}+\lambda\right)\right)\right)}{\frac{\varepsilon}{\mathrm{L}_{\mathrm{n}}}+\lambda}+$

$\frac{\mathrm{P}_{\mu \text { slow }} \cdot \exp \left(-\frac{\mathrm{x}}{\mathrm{L}_{\mu \text { slow }}}\right)\left(1-\exp \left(-\mathrm{t}\left(\frac{\varepsilon}{\mathrm{L}_{\mu \text { slow }}}+\lambda\right)\right)\right)}{\frac{\varepsilon}{\mathrm{L}_{\mu \text { slow }}}+\lambda}+\frac{\mathrm{P}_{\mu \text { fast }} \cdot \exp \left(-\frac{\mathrm{x}}{\mathrm{L}_{\mu \text { fast }}}\right)\left(1-\exp \left(-\mathrm{t}\left(\frac{\varepsilon}{\mathrm{L}_{\mu \text { fast }}}+\lambda\right)\right)\right)}{\frac{\varepsilon}{\mathrm{L}_{\mu \text { fast }}}+\lambda}$

(eq. 1)

where $\mathrm{C}(\mathrm{x}, \varepsilon, \mathrm{t})$ is the nuclide concentration as a function of the attenuation depth $x$ (typically expressed as a function of depth $z$, in $\mathrm{cm}$, and bedrock density $\rho$, in $\mathrm{g} / \mathrm{cm}^{3}$ ), denudation rate $\varepsilon, \varepsilon^{\prime}$ (in $\mathrm{g} / \mathrm{cm}^{2} / \mathrm{a}$ ), and exposure times and $\mathrm{t}^{\prime} t$ (in years). The term $\mathrm{C}\left(\mathrm{x}, \varepsilon^{\prime}, \mathrm{t}^{\prime}\right)$

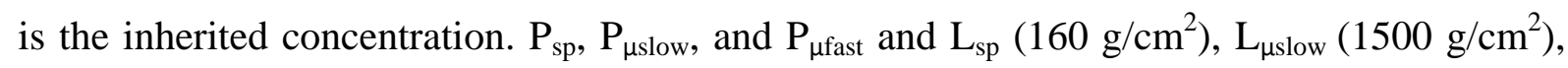
and $L_{\mu f a s t}\left(4320 \mathrm{~g} / \mathrm{cm}^{2}\right)$ (Braucher et al., 2011) are the production rates and attenuation lengths of neutrons, slow muons and fast muons, respectively; $\lambda$ is the radioactive decay constant of the TCN under investigation. $\mathrm{C}(\mathrm{x}, 0)$ is the ${ }^{10} \mathrm{Be}$ or ${ }^{26} \mathrm{Al}$ concentration that is acquired during periods of exposure time prior to denudation.

The chemical procedure for ${ }^{10} \mathrm{Be}$ and ${ }^{26} \mathrm{Al}$ extraction from all the samples to measure their ${ }^{10} \mathrm{Be}$ and ${ }^{26} \mathrm{Al}$ concentrations was conducted at CEREGE (Aix-en-Provence, France) and followed Brown et al. (1991) and Merchel and Herpers (1999). Pebbles were crushed and sieved (250-800- $\mu \mathrm{m}$ fraction). Quartz was concentrated through magnetic separation and selective dissolution in a $1 / 3 \mathrm{HCl}-2 / 3 \mathrm{H}_{2} \mathrm{SiF}_{6}$ mixture. Quartz was decontaminated from the atmospheric ${ }^{10} \mathrm{Be}$ by dissolving $30 \%$ in mass through three successive HF leaching steps. Pure 
quartz was then spiked with $100 \mu \mathrm{L}$ of a (3025 \pm )-ppm in-house ${ }^{9} \mathrm{Be}$ carrier (Merchel et al., 2008) and with an adapted amount of a $985 \mu \mathrm{g} / \mathrm{g}{ }^{27} \mathrm{Al}$ carrier. The natural ${ }^{27} \mathrm{Al}$ concentrations in the dissolved samples were measured by inductively coupled plasma optical emission spectrometry (ICP-OES) on an ICAP6500 Thermo Scientific unit spectrometer. We performed this analysis of replicate aliquots using two emission lines (394 and $396 \mathrm{~nm}$, axial sight) and two standards (Merck of $999 \pm 2 \mathrm{mg} / \mathrm{L}$, and Fluka TraceCert of $985 \pm 2 \mu \mathrm{g} / \mathrm{g}$ ). Finally, dissolution was conducted in concentrated HF.

The abundance of muscovites (with high ${ }^{27} \mathrm{Al}$ content) in the rocks from the watershed forced us to regularly check the purification of the samples with a binocular microscope. If not removed from the quartz before total dissolution, these muscovites would cause the formation of thick solid crusts, from which properly recovering all the dissolved aluminum would become difficult.

$\mathrm{BeO}$ and $\mathrm{Al}_{2} \mathrm{O}_{3}$ were then purified and extracted by using a succession of alkaline precipitation and separations on ionic-exchange resins (used exchange resins: DOWEX 1x8 100-200 mesh, DOWEX 50Wx8 100-200 mesh). Finally, full oxidization was performed at $700^{\circ} \mathrm{C}$ for one hour. The obtained $\mathrm{BeO}$ and $\mathrm{Al}_{2} \mathrm{O}_{3}$ oxides were mixed with $\mathrm{Nb}$ and $\mathrm{Ag}$ conductive powders, respectively, and then introduced in a copper cathode to be pressed. The ${ }^{10} \mathrm{Be} /{ }^{9} \mathrm{Be}$ and ${ }^{26} \mathrm{Al} /{ }^{27} \mathrm{Al}$ ratios were finally measured at the French national AMS facility ASTER. The measured ${ }^{10} \mathrm{Be} /{ }^{9} \mathrm{Be}$ ratios were calibrated against the ${ }^{10} \mathrm{Be} /{ }^{9} \mathrm{Be}$ SRM 4325 NIST (National Institute of Standards and Technology) standard with an assigned value of (2.79 \pm $0.03) \cdot 10^{-11}$ (Nishiizumi et al., 2007). The measured ${ }^{26} \mathrm{Al} /{ }^{27} \mathrm{Al}$ ratios were calibrated against the ASTER in-house standard SM-Al-11, whose nominal value is ${ }^{26} \mathrm{Al} /{ }^{27} \mathrm{Al}=(7.401 \pm$ 0.064) $10^{-12}$ (Merchel and Bremser, 2004). The half-lives $\left({ }^{10} \mathrm{Be}: 1.387 \pm 0.012 \mathrm{Ma}\right.$ (Korschinek et al., 2010; Chmeleff et al., 2010); ${ }^{26} \mathrm{Al}$ : $0.717 \pm 0.024$ Ma (Samworth et al., 1972)) and the standardization method that were used at ASTER (SM-Al-11/07KNSTD) implied that the ${ }^{26} \mathrm{Al} /{ }^{10} \mathrm{Be}$ spallation production ratio was $\sim 6.61 \pm 0.52$. Analytical uncertainties included the counting statistics, the machine's stability ( 0.5\%; Arnold et al., 2010 for ${ }^{10} \mathrm{Be}$ ) and blank correction.

All the calculations were conducted with a sea-level, high-latitude (SLHL) ${ }^{10} \mathrm{Be}$ spallation production rate of $4.01 \pm 0.18$ at $\mathrm{g}^{-1} \mathrm{a}^{-1}$ (Borchers et al., 2016), which was assumed to be constant over time and scaled for latitude (Stone, 2000) and elevation. Corrections for mass shielding were calculated by using the equation of Dunai (2009). Muon contributions from Braucher et al. (2011) were only scaled for altitude. The production rate is calculated for each cell of the $30 \mathrm{~m}$ ASTER DEM and the $9.03 \pm 0.95 \mathrm{at} / \mathrm{g}(\mathrm{Qz}) / \mathrm{yr}$ mean catchment production rate is computed following a Matlab script and the CREp tool (Martin et al., 2017), using a 
524 rock density of $2.5 \mathrm{~g} / \mathrm{cm}^{3}$. Areas without quartz-bearing rocks and not linked to the stream 525 network were excluded from calculations. No corrections were performed for ice cover since 526 it only represents a very small proportion of our studied area. We used the globally averaged 527 P10 obtained in CREp and the 21/10 production ratio (P21/P10=4.13) defined in Kober et al. 528 (2007).

\subsection{2. ${ }^{10} \mathrm{Be} /{ }^{21} \mathrm{Ne}-$ based burial duration determination}

The cosmogenic burial dating method was based on the evolution of the ${ }^{26} \mathrm{Al} /{ }^{10} \mathrm{Be}$ ratio and limited to the last $\sim 6 \mathrm{Ma}$, so we had to expand the investigated period to pinpoint the chronology of the valley incision. Thus, we implemented the cosmogenic burial dating method based on the evolution of the ${ }^{10} \mathrm{Be} /{ }^{21} \mathrm{Ne}$ ratio.

The neon isotopes, whose concentrations were measured on the Helix-SFT ${ }^{\mathrm{TM}}$ mass spectrometer at CRPG (Nancy, France), originated from both the fluid inclusions in the quartz minerals and the surface of the quartz grains. The same quartz fractions $(250-800 \mu \mathrm{m})$ as those that were used to determine the ${ }^{26} \mathrm{Al}$ and ${ }^{10} \mathrm{Be}$ concentrations were analyzed (same sample splits), even if the finest fraction was more suitable to reduce the contribution of atmosphere-like Ne that was trapped in the fluid inclusions. All the samples were wrapped in tin foil and loaded into the carousel of a new induction furnace that was designed at the CRPG lab (Zimmermann et al., 2017). Following conclusive validation tests, neon was extracted in one single heating step at $\sim 1500^{\circ} \mathrm{C}$ over at least $25 \mathrm{~min}$. Atmospheric contamination was low enough to ensure a proper estimate of the non-cosmogenic component. After gas extraction by heating, chemically active gases were removed in two $\mathrm{Ti}$ sponge getters; $\mathrm{Ar}-\mathrm{Kr}-\mathrm{Xe}$ was trapped in a charcoal finger at liquid-nitrogen temperature. $\mathrm{Ne}$ was cryo-focused at $35 \mathrm{~K}$ before being released at $90 \mathrm{~K}$. The neon concentrations and isotopic compositions were determined via peak jumping mass spectrometry by using detectors with multipliers. Neon isotopes were corrected for isobaric interferences, instrumental mass fractionation and analytical blanks. Aliquots of the quartz standard CRONUS-A that were measured during the sample batch yielded $\mathrm{a}^{21} \mathrm{Ne}$ excess of $(331 \pm 6) \cdot 10^{6} \mathrm{at} / \mathrm{g}$, which matched the reference concentration of $(348 \pm 10) .10^{6}$ at/g (Vermeesch et al., 2015).

The cosmogenic component was computed by using the following formula:

$$
{ }^{21} \mathrm{Ne}_{\text {cosmogenic }}={ }^{21} \mathrm{Ne}_{\text {sample }}-{ }^{20} \mathrm{Ne}_{\text {atmospheric }} \times\left(\frac{{ }^{21} \mathrm{Ne}}{{ }^{20} \mathrm{Ne}}\right)_{\text {air }}
$$


The concentration of excess ${ }^{21} \mathrm{Ne}\left({ }^{21} \mathrm{Ne} *\right)$ was determined as follows (Vermeesch et al., 2015):

$$
{ }^{21} \mathrm{Ne}^{*}=\mathrm{R}_{\mathrm{c}} \times{ }^{20} \mathrm{Ne}_{\mathrm{m}} \times \frac{\mathrm{R}_{\mathrm{m}}-\mathrm{R}_{\mathrm{a}}}{\mathrm{R}_{\mathrm{c}}-\mathrm{R}_{\mathrm{a}}}
$$

where ${ }^{20} \mathrm{Ne}_{\mathrm{m}}$ is the measured neon-20 concentration; $\mathrm{R}_{\mathrm{c}}=1.1$, the cosmogenic ${ }^{21} \mathrm{Ne} /{ }^{20} \mathrm{Ne}$ production ratio (Niedermann, 2002); $\mathrm{R}_{\mathrm{m}}$ is the measured ${ }^{21} \mathrm{Ne} /{ }^{20} \mathrm{Ne}$ ratio; and $\mathrm{R}_{\mathrm{a}}=$ 0.002905 , the atmospheric ${ }^{21} \mathrm{Ne} /{ }^{20} \mathrm{Ne}$ ratio (Honda et al., 2015).

\section{Results}

\section{1. ${ }^{10} \mathrm{Be}$ and ${ }^{26} \mathrm{Al}$}

All the measured ${ }^{10} \mathrm{Be}$ and ${ }^{26} \mathrm{Al}$ concentrations and the resulting ${ }^{26} \mathrm{Al} /{ }^{10} \mathrm{Be}$ ratios with their associated uncertainties are presented in Table $4 .{ }^{10} \mathrm{Be} /{ }^{9} \mathrm{Be}$ ratios that were significantly different from the background value, the mean analytical blank ${ }^{10} \mathrm{Be} /{ }^{9} \mathrm{Be}$ ratio being $(2.94 \pm$ 0.21). $10^{-15}$, were measured for all samples but F4C. They lead to ${ }^{10} \mathrm{Be}$ concentrations ranging from $(0.40 \pm 0.06)$ to $(51.1 \pm 17.5) .10^{4}$ atoms per gram. .

Some of the measured ${ }^{26} \mathrm{Al} /{ }^{27} \mathrm{Al}$ ratios were not significantly different from the analytical blank $\left((1.31 \pm 0.56) \cdot 10^{-15}\right)$, which suggests burial durations outside the methodological framework. For the remaining samples, the ${ }^{26} \mathrm{Al}$ concentrations range between $(1.25 \pm 0.74)$ and $(84.32 \pm 5.51) \cdot 10^{4}$ atoms per gram.

Only the ${ }^{10} \mathrm{Be} /{ }^{9} \mathrm{Be}$ ratios were measured in the samples from the Ours, Guano, Balcon, Nid, Roc Campagna, Roquefumade and Notre-Dame-de-Vie caves because of their high muscovite content (for the first two cases) or because of their ${ }^{26} \mathrm{Al} /{ }^{27} \mathrm{Al}$ ratios not significantly different from the background value.

All the burial durations and the derived maximum paleo-denudation rates (denudation rates that prevailed before the burial event ( $\varepsilon$ ' in equation 1 ), which were calculated by using either the ${ }^{26} \mathrm{Al} /{ }^{10} \mathrm{Be}$ ratios or the ${ }^{10} \mathrm{Be} /{ }^{21} \mathrm{Ne}$ ratios, are presented in Table 6 . In the river sands, the measured ${ }^{10} \mathrm{Be}$ and ${ }^{26} \mathrm{Al}$ concentrations were assumed to indicate the concentration of all quartz-bearing rocks that outcropped in the drainage basin, in addition to a sufficiently long exposure duration to reach a ${ }^{10} \mathrm{Be}-{ }^{26} \mathrm{Al}$ steady-state concentration (Brown et al., 1985). Thus, we could determine the average denudation rate for an entire drainage basin by measuring the cosmogenic nuclide concentration in riverbed sands. Tests with coherent sensible variations did not lead to significant differences, so an average paleo-elevation of the catchment basin that was similar to the current value was assumed. 


\begin{tabular}{|c|c|c|c|c|c|c|}
\hline & Sample & Site & Facies and lithologies & ${ }^{10} \mathrm{Be}(\mathrm{kat} / \mathrm{g})$ & ${ }^{26} \mathrm{Al}(\mathrm{kat} / \mathrm{g})$ & ${ }^{26} \mathrm{Al} /{ }^{10} \mathrm{Be}$ \\
\hline \multirow{27}{*}{ Caves } & PDR1 & Puits des Racines & 6 amalgamated pebbles (quarzites, gneiss, granites) & $39.13 \pm 5.66$ & $55.96 \pm 20.26$ & $1.43 \pm 0.56$ \\
\hline & PDR2 & Puits des Racines & Sand, fine & $113.76 \pm 9.09$ & $79.96 \pm 10.91$ & $0.70 \pm 0.11$ \\
\hline & PDR3 & Puits des Racines & Sand, medium to coarse & $116.29 \pm 4.27$ & $569.17 \pm 42.07$ & $4.89 \pm 0.40$ \\
\hline & PDR4 & Puits des Racines & $\begin{array}{c}15 \text { amalgamated pebbles \& gravels (quarzites, gneiss, } \\
\text { granites) }\end{array}$ & $126.11 \pm 11.15$ & $159.42 \pm 25.78$ & $1.26 \pm 0.23$ \\
\hline & PDR6 & Puits des Racines & 4 amalgamated weathered granites pebbles & $8.42 \pm 0.97$ & $20.99 \pm 8.06$ & $2.49 \pm 1.00$ \\
\hline & PDR7 & Puits des Racines & Sand, medium & $71.99 \pm 4.48$ & $477.82 \pm 47.18$ & $6.64 \pm 0.77$ \\
\hline & PDR8 & Puits des Racines & Quartzite pebble & $29.86 \pm 3.65$ & $125.42 \pm 27.33$ & $4.20 \pm 1.05$ \\
\hline & PDR10 & Puits des Racines & Gneiss pebble & $4.05 \pm 0.60$ & $17.24 \pm 12.75$ & $4.26 \pm 3.21$ \\
\hline & PDR12 & Puits des Racines & Quartzite pebble & $102.87 \pm 6.23$ & $542.57 \pm 55.72$ & $5.27 \pm 0.63$ \\
\hline & PDR13 & Puits des Racines & Granite pebble & $15.03 \pm 4.38$ & $23.78 \pm 17.38$ & $1.58 \pm 1.25$ \\
\hline & AM1 & Lachambre & Clast-supported gravel & $101.11 \pm 5.03$ & B.D.L & - \\
\hline & AM2 & Lachambre & Sand, medium to coarse & $120.27 \pm 10.31$ & $133.33 \pm 41.48$ & $1.11 \pm 0.36$ \\
\hline & AM3 & Lachambre & 7 amalgamated pebbles (quarzites, gneiss, granites) & $67.00 \pm 7.63$ & B.D.L & - \\
\hline & AM4 & Lachambre & 8 amalgamated pebbles (quarzites, gneiss, granites) & $203.78 \pm 11.97$ & $555.72 \pm 70.56$ & $2.73 \pm 0.38$ \\
\hline & AM5 & Lachambre & 4 amalgamated pebbles (quarzites, gneiss, granites) & $99.60 \pm 6.78$ & $388.99 \pm 85.26$ & $3.91 \pm 0.90$ \\
\hline & AM6 & Lachambre & 3 amalgamated pebbles (quarzites, gneiss, granites) & $101.40 \pm 5.21$ & $155.86 \pm 24.20$ & $1.54 \pm 0.25$ \\
\hline & AM7 & Lachambre & 8 amalgamated gneiss pebbles & $116.29 \pm 5.39$ & $640.06 \pm 65.94$ & $5.50 \pm 0.62$ \\
\hline & AM8 & Lachambre & 10 amalgamated granites pebbles & $72.01 \pm 8.35$ & $81.61 \pm 27.37$ & $1.13 \pm 0.40$ \\
\hline & AM9 & Lachambre & 8 amalgamated granites pebbles & $511.22 \pm 17.71$ & $2932.44 \pm 236.36$ & $5.74 \pm 0.50$ \\
\hline & MP1 & Mas-Py & Amalgamated pebbles and sands (fine to coarse) & $134.54 \pm 6.25$ & B.D.L & - \\
\hline & MP2 & Mas-Py & Medium to very coarse sand, may be pebbly & $171.11 \pm 7.12$ & $398.42 \pm 74.13$ & $2.33 \pm 0.44$ \\
\hline & MP3 & Mas-Py & Sand, medium to coarse & $150.17 \pm 11.07$ & $91.35 \pm 9.96$ & $0.61 \pm 0.08$ \\
\hline & MA2-1 & Malou-2 & Sand, medium & $127.25 \pm 5.74$ & $256.72 \pm 58.91$ & $2.02 \pm 0.47$ \\
\hline & OU1 & Ours & Clast-supported gravel & $84.23 \pm 10.83$ & B.D.L & - \\
\hline & OU2 & Ours & Clast-supported gravel & $68.78 \pm 11.34$ & B.D.L & - \\
\hline & GU1 & Guano & Coarse to very coarse sand, may be pebbly & $85.06 \pm 4.83$ & B.D.L & - \\
\hline & GU2 & Guano & Sand, fine to locally loamy & $56.78 \pm 2.66$ & B.D.L & - \\
\hline
\end{tabular}




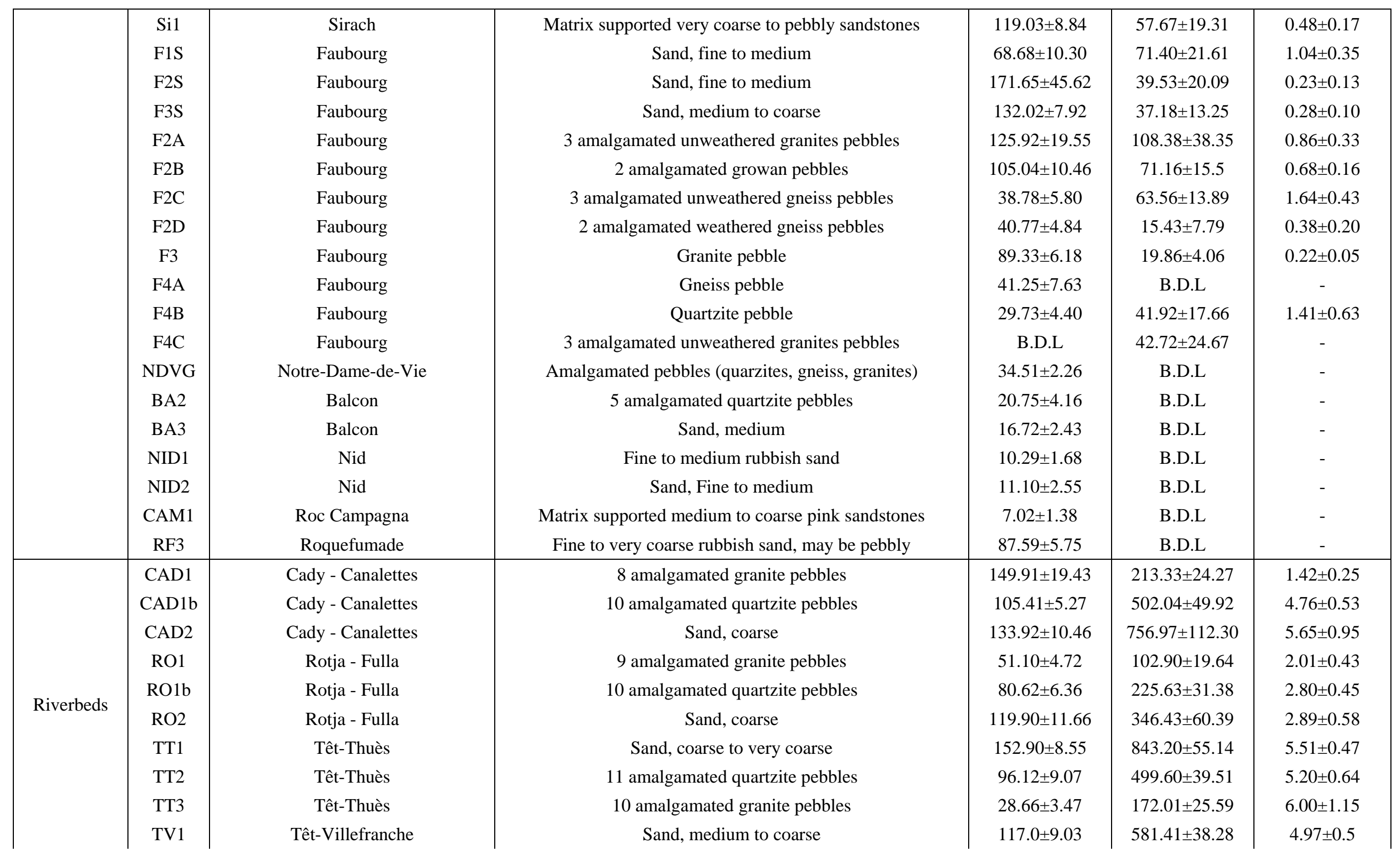




\begin{tabular}{|c|c|c|c|c|c|c|}
\hline & $\begin{array}{l}\text { TV2 } \\
\text { TV3 }\end{array}$ & $\begin{array}{l}\text { Têt-Villefranche } \\
\text { Têt-Villefranche }\end{array}$ & $\begin{array}{l}12 \text { amalgamated quartzite pebbles } \\
12 \text { amalgamated granite pebbles }\end{array}$ & $\begin{array}{c}93.88 \pm 7.20 \\
73.95 \pm 10.80\end{array}$ & $\begin{array}{r}226.45 \pm 30.07 \\
59.05 \pm 14.42\end{array}$ & $\begin{array}{l}2.41 \pm 0.37 \\
0.80 \pm 0.23\end{array}$ \\
\hline \multirow{6}{*}{$\begin{array}{l}\text { Escaro } \\
\text { formation }\end{array}$} & EB1 & $\begin{array}{l}\text { Escaro quarry - base of the } \\
\text { formation }\end{array}$ & 5 amalgamated quartzite pebbles & $9.58 \pm 1.13$ & $27.88 \pm 12.48$ & $2.91 \pm 1.35$ \\
\hline & EB2 & $\begin{array}{l}\text { Escaro quarry - base of the } \\
\text { formation }\end{array}$ & 6 amalgamated altered gneiss pebbles & $10.86 \pm 2.45$ & $20.02 \pm 20.01$ & $1.84 \pm 1.89$ \\
\hline & EB3 & $\begin{array}{l}\text { Escaro quarry - base of the } \\
\text { formation }\end{array}$ & Sand, fine to medium & $9.62 \pm 1.19$ & $12.55 \pm 7.37$ & $1.30 \pm 0.78$ \\
\hline & ET1 & Escaro quarry - halfway up bench & 7 amalgamated altered gneiss pebbles & $6.55 \pm 1.24$ & $57.88 \pm 33.86$ & $8.84 \pm 5.43$ \\
\hline & ET2 & Escaro quarry - halfway up bench & 6 amalgamated quartzite pebbles & $24.59 \pm 5.10$ & $31.11 \pm 8.63$ & $1.26 \pm 0.44$ \\
\hline & ET3 & Escaro quarry - halfway up bench & Sand, fine to medium & $8.90 \pm 0.97$ & $18.26 \pm 6.00$ & $2.05 \pm 0.71$ \\
\hline
\end{tabular}


A significant dispersion of the cosmogenic nuclide ratios independent of the stage

590

591

592

593

594

595

596

597

598

599

600

601

602

603

604

605

606

607

608

609

610

611

612

613

614

615

616

617

618

619

620

621

\section{3} within the same cave, which led to significantly different burial durations, was highlighted (Tables 4 and 5) for the Lachambre network (AM samples), the En Gorner network (PDR samples) and the Mas-Py cave (MP samples). The Faubourg cave contained two distinct populations: one was centered on a ${ }^{26} \mathrm{Al} /{ }^{10} \mathrm{Be}$ ratio of $(0.89 \pm 0.17)$, which implies a burial duration of roughly $3 \mathrm{Ma}$, and another was centered on a ${ }^{26} \mathrm{Al} /{ }^{10} \mathrm{Be}$ ratio of $(0.27 \pm 0.08)$, which implies a burial duration of roughly $6 \mathrm{Ma}$. Determining whether the samples with a deduced burial duration of $\sim 3 \mathrm{Ma}$ are an exception or if the cavity would have undergone two episodes of filling is difficult because the geometry of the deposits does not provide any clues to this subject. Concerning these samples, no influence from the analyzed lithology or the size of the particles could be considered (Table 4).

At the most upstream point at Thuès-entre-Valls (TT1, TT2 and TT3 samples; Table 4), the ${ }^{26} \mathrm{Al} /{ }^{10} \mathrm{Be}$ ratios are inter-consistent no matter the particle size or lithology. The same trend was observed for the Rotja samples (RO1, RO1b and RO2; Table 4). Their ${ }^{26} \mathrm{Al} /{ }^{10} \mathrm{Be}$ ratios indicated burial episodes, so the Rotja samples could have been buried in the Rotja catchment before being remobilized by the river. The ${ }^{26} \mathrm{Al} /{ }^{10} \mathrm{Be}$ ratios of the Cady (CAD1, $\mathrm{CAD} 1 \mathrm{~b}$ and $\mathrm{CAD} 2$; Table 4) were scattered, and the pebbles indicated burial episodes. Moreover, the ${ }^{26} \mathrm{Al} /{ }^{10} \mathrm{Be}$ ratios of quartzites were similar to those of sands but were significantly different from those of granites. Finally, the ${ }^{26} \mathrm{Al} /{ }^{10} \mathrm{Be}$ ratios of the samples from the Têt at Villefranche-de-Conflent (TV1, TV2 and TV3; Table 4) after the confluence with the Rotja were scattered and significantly different from those of the Thuès-entre-Valls (TT1, TT2 and TT3) samples. This difference was particularly striking for the granite pebbles.

4.2. ${ }^{21} \mathrm{Ne}$

All the neon measurements are presented in Table 5.

All the samples in the neon three-isotope diagram (Figure 6) plotted on the spallation line because of their associated uncertainties, which confirms the cosmogenic origin of the ${ }^{21} \mathrm{Ne}$ and ${ }^{22} \mathrm{Ne}$ in excess relative to the atmospheric end-member. In addition, the reextractions that were conducted between 1446 and $1469^{\circ} \mathrm{C}$ were not significantly different from the background, demonstrating that all the neon had been initially extracted.

19 No ${ }^{21} \mathrm{Ne}$ concentrations were determined for the samples from caves at the base of the staging (AM4 (Lachambre network), OU1 (Ours cave) and PDR3 (En Gorner network)) because the measured ratios were not significantly different from those in the air. 


\begin{tabular}{|c|c|c|c|c|c|c|}
\hline Sample & Cave & Mass (mg) & ${ }^{21} \mathrm{Ne}^{* / 20} \mathrm{Ne}^{*}\left(\mathrm{x} 10^{3}\right)$ & ${ }^{22} \mathrm{Ne}^{*} /{ }^{20} \mathrm{Ne}^{*}(\mathrm{x} 10)$ & ${ }^{20} \mathrm{Ne}$ (Gat/g) & ${ }^{21} \mathrm{Ne}$ (Mat/g) \\
\hline MP2 & Mas-Py & 111.8 & $2.905 \pm 0.041$ & $1.009 \pm 0.007$ & $4.62 \pm 0.31$ & $0.59 \pm 0.19$ \\
\hline MA2-1 & Malou-2 & 109.0 & $3.227 \pm 0.052$ & $1.008 \pm 0.008$ & $3.76 \pm 0.25$ & $1.77 \pm 0.2$ \\
\hline Si1 & Sirach & 165.3 & $3.496 \pm 0.052$ & $1.005 \pm 0.007$ & $2.78 \pm 0.18$ & $2.1 \pm 0.14$ \\
\hline F1S & Faubourg & 289.9 & $3.604 \pm 0.2$ & $1.045 \pm 0.033$ & $1.29 \pm 0.05$ & $1.02 \pm 0.26$ \\
\hline $\mathrm{F} 2 \mathrm{~S}$ & Faubourg & 382.4 & $3.472 \pm 0.051$ & $1.044 \pm 0.008$ & $1.7 \pm 0.06$ & $1.12 \pm 0.09$ \\
\hline F3S & Faubourg & 300.6 & $3.176 \pm 0.044$ & $1.042 \pm 0.007$ & $2.91 \pm 0.1$ & $1.03 \pm 0.13$ \\
\hline GU1 & Guano & 111.0 & $3.637 \pm 0.081$ & $0.998 \pm 0.013$ & $2.16 \pm 0.14$ & $1.96 \pm 0.18$ \\
\hline NDVG & Notre-Dame-de-Vie & 363.3 & $3.338 \pm 0.061$ & $1.048 \pm 0.009$ & $2.4 \pm 0.08$ & $1.24 \pm 0.15$ \\
\hline BA2 & Balcon & 336.1 & $3.576 \pm 0.045$ & $1.072 \pm 0.008$ & $3.17 \pm 0.11$ & $2.42 \pm 0.14$ \\
\hline BA3 & Balcon & 300.4 & $3.423 \pm 0.03$ & $1.051 \pm 0.007$ & $2.86 \pm 0.1$ & $1.74 \pm 0.09$ \\
\hline NID2 & Nid & 284.2 & $3.845 \pm 0.073$ & $1.049 \pm 0.012$ & $1.57 \pm 0.05$ & $1.63 \pm 0.11$ \\
\hline CAM1 & Roc Campagna & 264.8 & $3.877 \pm 0.035$ & $1.031 \pm 0.004$ & $6.78 \pm 0.45$ & $7.88 \pm 0.24$ \\
\hline & & 225.7 & $3.9 \pm 0.049$ & $1.01 \pm 0.006$ & $6.59 \pm 0.44$ & $7.91 \pm 0.32$ \\
\hline AM4 & Lachambre & 126.1 & $2.649 \pm 0.043$ & $1.001 \pm 0.007$ & $4.11 \pm 0.27$ & - \\
\hline OU1 & Ours & 82.8 & $2.799 \pm 0.095$ & $0.989 \pm 0.016$ & $2.35 \pm 0.16$ & - \\
\hline
\end{tabular}

622 Table 5: Ne isotope ratios and derived cosmogenic ${ }^{21} \mathrm{Ne}$ concentrations.

623 The Balcon and Nid caves, which are located at the same elevation, produced similar $624{ }^{10} \mathrm{Be} /{ }^{21} \mathrm{Ne}$ burial durations: their ${ }^{26} \mathrm{Al} /{ }^{27} \mathrm{Al}$ ratios were not significantly different from the 625 background value because of the complete radioactive decay of all their initially accumulated $626{ }^{26} \mathrm{Al}$

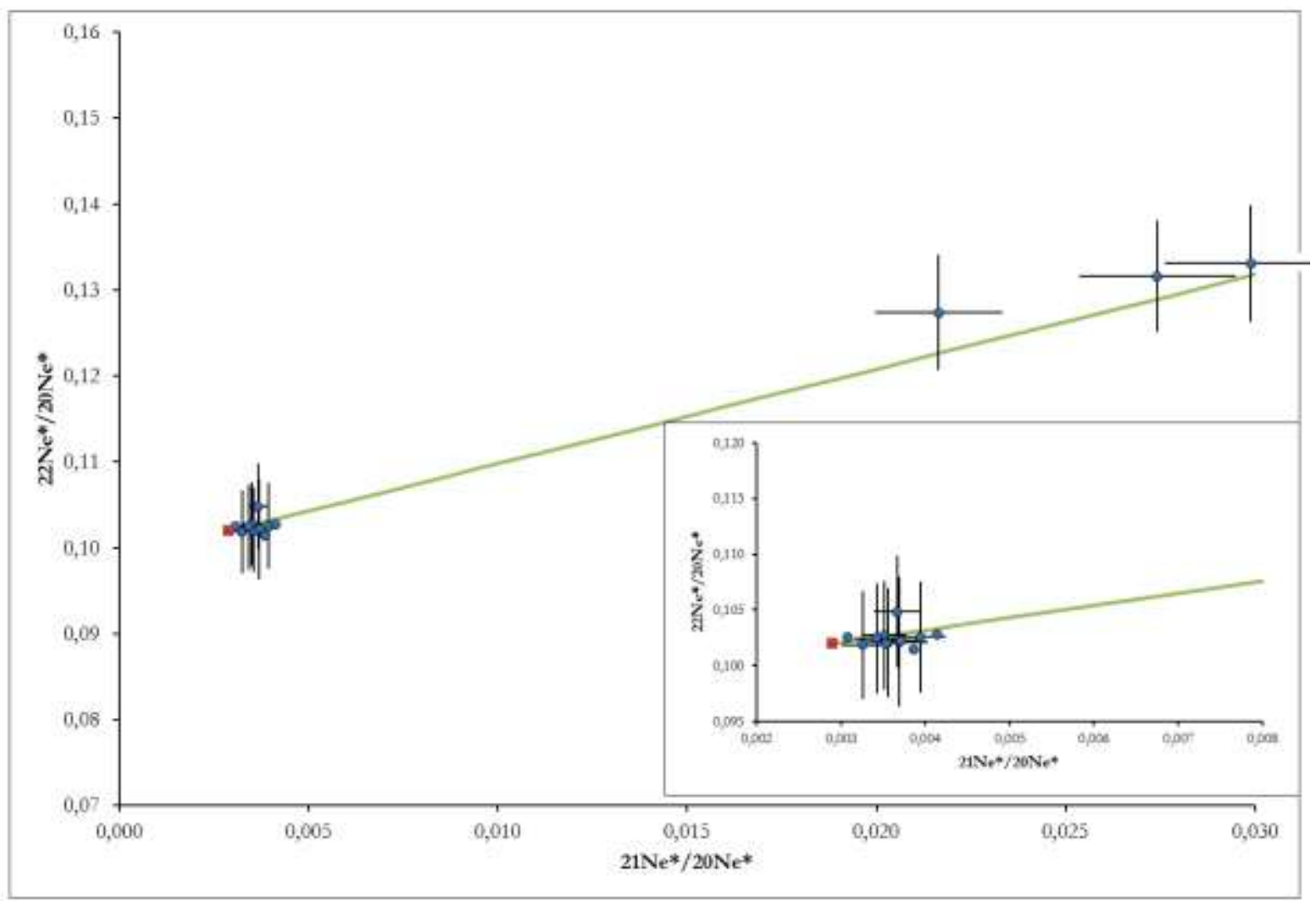
data from the Têt samples (blue circles) plot on the green spallation line. 


\subsubsection{Usefulness of ${ }^{26} \mathrm{Al} /{ }^{10} \mathrm{Be}$ and ${ }^{10} \mathrm{Be} /{ }^{21} \mathrm{Ne}$ comparisons}

Although the ${ }^{26} \mathrm{Al}-{ }^{10} \mathrm{Be}^{21} \mathrm{Ne}$ combination is the most obvious to solve the inconsistencies and enhance the validity of the proposed burial durations, a thorough comparison of the burial durations from samples within the same deposits with both implemented burial dating methods is difficult within the framework of this study. Indeed, the most perched stages had measured ${ }^{26} \mathrm{Al} /{ }^{27} \mathrm{Al}$ ratios that were not significantly different from the background, and the cosmogenic neon concentrations within the samples from the Lachambre and En Gorner networks were below the detection limit.

Nevertheless, when possible, this comparison is informative. For the highest caves in which this comparison is possible (Faubourg (F2S and F3S) and Sirach (Si1)) and in the MasPy (MP2) cave, the burial durations that were deduced by using both burial dating methods agreed within the uncertainties (Table 6; Figure 7). An interesting case concerned the samples from the lowest floors of the Malou2 cave (MA2-1) and Faubourg cave (F1S). The ${ }^{26} \mathrm{~A} 1 /{ }^{10} \mathrm{Be}$ ratios of these samples were reassessed (Calvet et al., 2015), and the burial durations from their respective ${ }^{26} \mathrm{Al} /{ }^{10} \mathrm{Be}$ and ${ }^{10} \mathrm{Be} /{ }^{21} \mathrm{Ne}$ ratios were significantly different. We propose that these differences may reflect either complex histories of multiple burials and re-exposures or mixtures of sediments of different ratios. Although the ${ }^{26} \mathrm{Al} /{ }^{10} \mathrm{Be}$ ratio could recover its surface value through multiple burials and re-exposures, this phenomenon is most likely not possible for the ${ }^{10} \mathrm{Be} /{ }^{21} \mathrm{Ne}$ ratio because ${ }^{21} \mathrm{Ne}$ is a stable isotope. This finding is coherent with the ${ }^{26} \mathrm{Al} /{ }^{10} \mathrm{Be}$-deduced burial duration, which was roughly 2 times lower than the ${ }^{10} \mathrm{Be} /{ }^{21} \mathrm{Ne}$ deduced burial duration. Regarding the second proposition, mixtures of sediments of different ratios may occur between two levels that are linked by a vertical connection or may result from external events, such as (i) more pronounced basal stagnation phases (as it is potentiality the case in Arkansas (Keen-Zebert et al., 2016; Paces et al., 2017)) with the remobilization of previous deposits; or (ii) substantial fluctuations in the base level, which led to the partial reuse of the ducts, remobilization of previous deposits, and potential refreshment of the morphologies. Indeed, if the sediments have not had time to consolidate, their remobilization may have erased old morphologies. However, this last hypothesis seems likely because of the on-site remodeling of sand or pebbles from 4 to $7 \mathrm{Ma}$. Indeed, these networks seem to have fluvial sediments that form the same sedimentary deposit. This hypothesis is difficult to verify with few stratigraphic elements that could also be linked to the ultimate deposition phase in some cavities. Nevertheless, this hypothesis might explain why "free" sands (PDR2, for example) have higher burial durations than consolidated sands in stratigraphy or clasts. 

In the context of the second hypothesis, we investigated one of the most significant 668 sedimentary deposits in the study area, namely, the Escaro Formation, to examine the 669 potential influence of sediments that are drained at the surface from sedimentary deposits on 670 the measured cosmogenic nuclide ratios in cave deposits. The formation of the Col de Fins, 671 which is supposedly of Neogene age, and the terrace levels were not considered here but 672 could have also played a role.

\begin{tabular}{|c|c|c|c|c|}
\hline Sample & Site & $\begin{array}{c}{ }^{26} \mathrm{Al} /{ }^{10} \mathrm{Be} \\
\text { burial } \\
\text { duration } \\
\text { (Ma) }\end{array}$ & $\begin{array}{c}{ }^{10} \mathrm{Be} /{ }^{21} \mathrm{Ne} \\
\text { burial } \\
\text { duration } \\
\text { (Ma) }\end{array}$ & $\begin{array}{c}\text { Derived } \\
\text { paleodenudation } \\
\text { rate }(\mathrm{cm} / \mathbf{k a})\end{array}$ \\
\hline PDR1 & En Gorner & $3.12 \pm 0.8$ & & $11.4 \pm 1.7$ \\
\hline PDR2 & En Gorner & $4.58 \pm 0.33$ & & $3.9 \pm 0.3$ \\
\hline PDR3 & En Gorner & $0.58 \pm 0.17$ & & $3.8 \pm 0.1$ \\
\hline PDR4 & En Gorner & $3.37 \pm 0.38$ & & $3.5 \pm 0.3$ \\
\hline PDR6 & En Gorner & $1.97 \pm 0.83$ & & $53.3 \pm 6.1$ \\
\hline PDR7 & En Gorner & $0.12 \pm 0.24$ & & $6.2 \pm 0.4$ \\
\hline PDR8 & En Gorner & $0.9 \pm 0.51$ & & $15 \pm 1.8$ \\
\hline PDR10 & En Gorner & $0.87 \pm 1.55$ & & $110.8 \pm 16.4$ \\
\hline PDR12 & En Gorner & $0.43 \pm 0.25$ & & $4.3 \pm 0.3$ \\
\hline PDR13 & En Gorner & $2.91 \pm 1.62$ & & $29.8 \pm 8.7$ \\
\hline AM2 & Lachambre & $3.65 \pm 0.89$ & & $5.1 \pm 0.4$ \\
\hline AM4 & Lachambre & $1.82 \pm 0.41$ & & $3 \pm 0.2$ \\
\hline AM5 & Lachambre & $1.05 \pm 0.47$ & & $4.5 \pm 0.3$ \\
\hline AM6 & Lachambre & $2.97 \pm 0.34$ & & $4.4 \pm 0.2$ \\
\hline AM7 & Lachambre & $0.34 \pm 0.23$ & & $3.9 \pm 0.2$ \\
\hline AM8 & Lachambre & $3.59 \pm 0.73$ & & $6.3 \pm 0.7$ \\
\hline AM9 & Lachambre & $0.26 \pm 0.18$ & & $0.9 \pm 0.5$ \\
\hline MP2 & Mas-Py & $2.3 \pm 0.44$ & $4.33 \pm 2.61$ & $3.6 \pm 0.2$ \\
\hline MP3 & Mas-Py & $4.88 \pm 0.27$ & & $3.1 \pm 0.2$ \\
\hline MA2-1 & Malou-2 & $2.59 \pm 0.61$ & $7.12 \pm 0.96$ & $5.2 \pm 0.8$ \\
\hline GU1 & Guano & - & $8.13 \pm 0.85$ & $0.3 \pm 0.0$ \\
\hline Sil & Sirach & $5.41 \pm 1.88$ & $7.6 \pm 0.81$ & $5.2 \pm 0.6$ \\
\hline F1S & Faubourg & $3.77 \pm 0.7$ & $6.87 \pm 2.1$ & $2 \pm 0.4$ \\
\hline $\mathrm{F} 2 \mathrm{~S}$ & Faubourg & $6.87 \pm 1.18$ & $7.13 \pm 0.98$ & $7 \pm 0.9$ \\
\hline F3S & Faubourg & $6.38 \pm 2.35$ & $6.37 \pm 1.12$ & $4.6 \pm 1.7$ \\
\hline $\mathrm{F} 2 \mathrm{~A}$ & Faubourg & $4.2 \pm 0.91$ & & $4.5 \pm 0.7$ \\
\hline F2B & Faubourg & $4.69 \pm 0.72$ & & $5.4 \pm 0.5$ \\
\hline $\mathrm{F} 2 \mathrm{C}$ & Faubourg & $2.87 \pm 0.36$ & & $14.7 \pm 2.2$ \\
\hline F2D & Faubourg & $5.89 \pm 2.77$ & & $14 \pm 1.7$ \\
\hline $\mathrm{F} 3$ & Faubourg & $6.98 \pm 1.92$ & & $6.3 \pm 0.4$ \\
\hline F4B & Faubourg & $3.18 \pm 0.67$ & & $19.2 \pm 2.9$ \\
\hline NDVG & Notre-Dame-de-Vie & - & $9.03 \pm 1.07$ & $0.2 \pm 0.0$ \\
\hline BA2 & Balcon & - & $11.88 \pm 1.68$ & $0.1 \pm 0.0$ \\
\hline BA3 & Balcon & - & $11.78 \pm 1.23$ & $0.1 \pm 0.0$ \\
\hline NID2 & Nid & - & $11.84 \pm 1.93$ & $0.1 \pm 0.0$ \\
\hline CAM1 & Roc Campagna & - & $15.92 \pm 1.59$ & $0.1 \pm 0.0$ \\
\hline CAD1 & Cady - Canalettes & - & & $3.5 \pm 0.5$ \\
\hline CAD1b & Cady - Canalettes & - & & $5 \pm 0.3$ \\
\hline CAD2 & Cady - Canalettes & - & & $3.9 \pm 0.3$ \\
\hline $\mathrm{RO} 1$ & Rotja - Fulla & - & & $10.7 \pm 1$ \\
\hline
\end{tabular}




\begin{tabular}{|c|c|c|c|}
\hline RO1b & Rotja - Fulla & - & $6.8 \pm 0.5$ \\
\hline $\mathrm{RO} 2$ & Rotja - Fulla & - & $4.5 \pm 0.4$ \\
\hline TT1 & Têt-Thuès & - & $4.5 \pm 0.3$ \\
\hline TT2 & Têt-Thuès & - & $7.1 \pm 0.7$ \\
\hline TT3 & Têt-Thuès & - & $24.1 \pm 2.9$ \\
\hline TV1 & Têt-Villefranche & - & $4.5 \pm 0.4$ \\
\hline TV2 & Têt-Villefranche & - & $5.6 \pm 0.4$ \\
\hline TV3 & Têt-Villefranche & - & $7.2 \pm 1.1$ \\
\hline EB1 & $\begin{array}{l}\text { Escaro quarry - base of the } \\
\text { formation }\end{array}$ & $1.65 \pm 0.95$ & $46.8 \pm 5.5$ \\
\hline EB2 & $\begin{array}{l}\text { Escaro quarry - base of the } \\
\text { formation }\end{array}$ & $2.63 \pm 2.26$ & $70.8 \pm 16$ \\
\hline EB3 & $\begin{array}{c}\text { Escaro quarry - base of the } \\
\text { formation }\end{array}$ & $3.34 \pm 0.95$ & $79.9 \pm 9.9$ \\
\hline ET1 & Escaro quarry - halfway up bench & - & $115.4 \pm 21.9$ \\
\hline ET2 & Escaro quarry - halfway up bench & $3.4 \pm 0.59$ & $30.7 \pm 6.4$ \\
\hline ET3 & Escaro quarry - halfway up bench & $2.37 \pm 0.71$ & $50.4 \pm 5.5$ \\
\hline
\end{tabular}

Table 6: Burial durations that were calculated with either the ${ }^{26} \mathrm{Al} /{ }^{10} \mathrm{Be}$ ratios or the ${ }^{10} \mathrm{Be} /{ }^{21} \mathrm{Ne}$ ratios and derived maximum paleo-denudation rates. Note that the ${ }^{10} \mathrm{Be}$ concentration is used by default for derived paleodenudation rate calculations.

As suggested by the riverbed samples (Table 6), it is likely that sediments of the Cady and Rotja rivers have experienced a different history from than those of the Têt River, influencing the ${ }^{26} \mathrm{Al} /{ }^{10} \mathrm{Be}$ ratios measured in the latter. Based on these findings, the favored explanation is that the streams that are draining the Escaro Formation are reworking material that had already been buried. Once trapped in the cave deposits, these sediments increased the variability of the determined ${ }^{26} \mathrm{Al} /{ }^{10} \mathrm{Be}$ ratios and, therefore, the deduced burial durations and paleo-denudation rates if the sole burial event in the cave was considered.

According to this scenario, sediments that are collected in such cavities may therefore have ${ }^{26} \mathrm{Al}$ and ${ }^{10} \mathrm{Be}$ concentrations (and thus final ${ }^{26} \mathrm{Al} /{ }^{10} \mathrm{Be}$ ratios) that indicate a burial in the cave that was associated with one pre-burial episode.

Although all the studied caves could present this bias, extrapolating this scenario to the upper stages, whose burial durations are clustered for the Nid and Balcon caves and the dispersion reduced for the Faubourg cave, is more difficult. Moreover, if the burial duration that was determined in this study for the Escaro Formation was proven, the bias that was induced by this pre-buried material would involve only the lowest stages, which probably developed within the same temporal range. Indeed, samples from the Escaro Formation produced burial durations from $2.63 \pm 2.26 \mathrm{Ma}$ to $3.40 \pm 0.59 \mathrm{Ma}$ (Figure 5; Table 6). Such late Pliocene ages for the deposition of this formation match a hypothesis that was proposed by some authors (Pannekoek, 1935; Oele et al., 1963; Clauzon et al., 2015) but rejected by others (Guitard et al., 1998 and references therein).

Thus, as previously highlighted, the main difficulty from the Têt river valley context is to approximately quantify the effect of the detrital formations on the exhibited records 
because their quartz grains have experienced multiple burial/exposure cycles. Indeed, some

699 authors (Calvet, 1996 and references therein) reported sufficient thicknesses for these formations to influence all the cavities of the staging. If true, all the analyzed sediments could have had an initial ratio that was more or less different from the expected theoretical production ratio when assuming only one burial event (Laureano et al., 2016). Nonetheless, the clustering of the results for the most perched levels, when sampling several deposits or several caves at the same level was possible, questions the possibility of such an inheritance for these perched levels because of the agreement of the burial durations from both burial dating methods. However, the clustering of their burial durations may have also resulted from a statistical bias. Indeed, few cavities could be studied at high altitudes. Moreover, these cavities exhibited slight development and were small sections, which may not have always been the case because of the morphology of the valley (Figure 2). This finding questions the representativeness of the sampled deposits. Indeed, the retreat of the cliffs could erase morphologies that are essential to the interpretations. In addition, the elevation of the current section may not be representative of the average altitude of the cavities or the altitude of the base levels at the time of their development. It is therefore critical to have the best possible cavity mappings and associated morphological measurements to insure an as accurate as possible altitude location of the selected samples. Finally, only a few remaining deposits are available in the majority of cases, particularly for the most perched levels. Therefore, identifying potential multiple phases of deposition is not guaranteed.

Moreover, the age from the measured ${ }^{26} \mathrm{Al} /{ }^{10} \mathrm{Be}$ ratios of the Escaro Formation (Table 6) has geodynamic implications that contradict those from a Lower Burdigalian age ( $20 \mathrm{Ma}$; Baudelot et Crouzel, 1974) based on the occurrence of Lentilla mammal fauna within the same formation and lateral shift in facies (Calvet, 1996 and references therein). Similarly, the thermochronological data from Maurel et al. (2008) suggested a contrasting thermal history that was recorded by two gneiss blocks, with one annealing interpreted as a geothermal effect that occurred during the replay of a fault in the basin $\sim 10$ Ma ago. These estimates contradict a Pliocene age based on an apparent continuity and a facies analogy with the Roussillon deposits (e.g., Clauzon et al., 2015 and references therein). To resolve these controversies, investigating other available outcrops near rivers, badlands and mammalian deposits in the Col de Fins and Escaro detrital formations is important to constrain their ages and potentially discard diachronic emplacements.

\subsection{Tentative evolution of the Conflent valley since the Burdigalian}

\subsubsection{Early and Mid-Miocene evolution of the Têt River valley}



of the valley can nevertheless be proposed based on the acquired data (Figure 7). The reconstructed "continuous" record of incision evidenced successive stages since the Burdigalian. During the formation of horizontal networks, phases of incision and stagnation must succeed one another (Audra, 1994). Although we cannot accurately constrain when the incision was initiated in the studied area, the results for the Roc Campagna cave enabled us to pinpoint its initiation between 14 and 18 Ma. Several samples were analyzed in the corresponding perched cavities, the burial durations were seemingly clustered from the Burdigalian to the Serravallian. However, only sections of galleries with low development remained, which raises the question of the representativeness of the sampled deposits. Nevertheless, these data from the beginning of the record to approximately $11-11.5 \mathrm{Ma}$ produced incision rates from 17 to $21 \mathrm{~m} / \mathrm{Ma}$ (Figure 7).

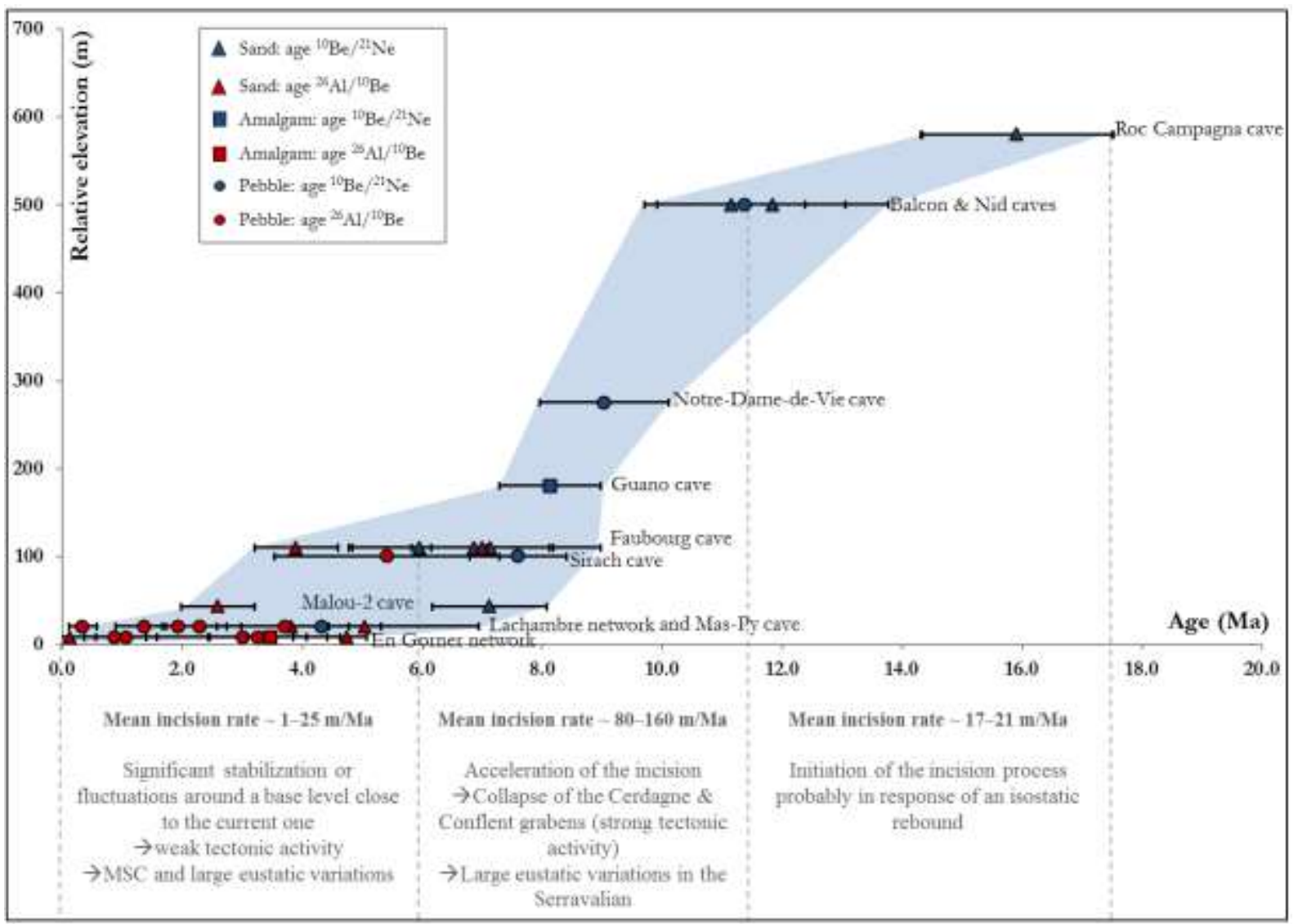
Serravalian

Figure 7: Evolution of the Têt canyon since the Burdigalian. The deduced burial durations from the were obtained according to the relative altitudes between two cave entries and the burial durations for these two levels. The small variations in relative altitudes, which were related to gaps in the networks, were included in the uncertainties. The Faubourg and Sirach caves are considered at the same level but on different banks. The same principle was applied to the Lachambre and En Gorner networks. The results for the En Gorner (Puits des Racines), Faubourg and Lachambre networks were not represented 
A significant acceleration of the incision (from $x 4$ to $x 6$ ) occurred at around $11-11.5$ Ma. This intensification seemed to continue until approximately 6 to $8 \mathrm{Ma}$ ago.

756

757

758

759

760

761

762

763

764

765

The eastern area of the Pyrenees could have been affected by crustal thinning during the $18-14$ Ma time interval, either after the collision phase or during the last phase of convergence, because of rifting that was linked to the opening of the Gulf of Lion during the Oligo-Miocene (Mauffret et al., 2001). Thenceforth, an uplift episode from an isostatic rebound that was caused by lithospheric thinning in the eastern Pyrenees in response to the opening of the Gulf of Lion and the uplifting of the Canigou massif may have occurred (Maurel et al., 2008). Other hypotheses have been proposed, such as the thermal erosion of the crustal root (Gunnell et al., 2008) or a still-active delamination phenomenon (Vanderhaeghe and Grabkowiak, 2014). Recent geophysical data for the crustal root that were published by Chevrot et al. (2014) did not seem to contradict these assumptions. Therefore, a combination of these phenomena may have been responsible for the initiation of the incision phenomenon, which was mainly linked to an internal forcing.

According to Mauffret et al. (2001), a second phase of Late-Miocene extension (anteMessinian) from 11.5 -11 Ma to 6 Ma would have caused the formation of the majority of the faults. Additionally, the opening of the grabens of Cerdagne and Conflent occurred from $\sim 12$ and $\sim 24$ to 6 Ma, respectively (e.g., Guitard et al., 1998). At around the Langhian Serravallian transition, the global sea level dropped from +90 to -100 m (e.g., Haq et al., 1987). The initiation of the incision acceleration along the record that was reconstructed from this study corresponds to both the opening of the Conflent graben and the drastic Langhian Serravallian base-level drop. However, can an extensional episode generate incision? The potential creation of relief during this extension episode could have indeed accentuated the incision. .Are internal forcings the only possible explanation? Furthermore, why did we not observe a record that was perturbed by an external forcing, such as base level variations, over this period? Base-level fluctuations were most likely not detectable from the Langhian to the Messinian because of the low proportion of remaining conduits and/or the absence of cavities at the pertinent altimetric range.

Finally, if incision from the Burdigalian to the Messinian was caused by both an uprising and variations in the global base level, this could have not been recorded in our dataset because such changes are too subtle in view of the low resolution of the record. Anyway, drawing conclusions regarding the controls of the Miocene incision remains difficult.

\subsubsection{Messinian to present evolution of the Têt River valley}


The deduced burial durations during the recent Miocene were scattered at each sampled cave (Figure 7). As previously presented and discussed, this finding may have resulted from the scattered initial ${ }^{26} \mathrm{Al} /{ }^{10} \mathrm{Be}$ ratios of the sediments that were deposited within the cavities, which depend on both the pre-burial episode histories and proportion of the Escaro Formation material that was remobilized by the Cady and Rotja rivers and included in the sampled deposits. These rivers specifically contributed to the formation of the Lachambre network and the Ours and Mas-Py caves (right bank of the Têt), which could explain both the scattering of the deduced burial duration in the Lachambre network and the discrepancies between the ${ }^{10} \mathrm{Be} /{ }^{21} \mathrm{Ne}$ and ${ }^{26} \mathrm{Al} /{ }^{10} \mathrm{Be}$ burial durations at the Mas-Py cave. However, such dispersions can also be explained by differences in grain sizes (e.g., Codilean et al., 2014), variability in the sources of the catchment, temporary sediment storages (e.g., Wittmann et al., 2011), or stochastic phenomena.

Moreover, global events such as the Messinian Salinity Crisis (MSC, e.g., Clauzon et al., 2015) and the low Pliocene tectonic activity in this area (Delcaillau et al., 2004) may have also been involved in the production of the obtained record, further complicating our interpretations. According to Loget et al. (2005), the MSC caused the fast retreat of the shoreline at the Bourcart canyon $(\sim 140 \mathrm{~km}$ between 5.6 and $5.46 \mathrm{Ma})$, which prevented regressive erosion waves from reaching the Têt canyon. The subsequent rise in the overall base level would have been even more intense, probably biphasic, with an episode from 5.46 to $5.33 \mathrm{Ma}$ followed by an almost instantaneous episode whose duration was estimated at 11 years (Pérez-Asensio et al., 2013). Such time intervals would not allow the whole drainage system to amortize these events given the conclusions regarding the migration rate of knickpoints drawn by Loget and Van Den Driessche (2009). A very intense sedimentation phase then occurred in the Roussillon plain, and remnants of Pliocene marine deposits can be observed $7 \mathrm{~km}$ from Prades, east of Marquixanes (see Figure 1 for these cities' locations). Furthermore, Molliex et al. (2016) calculated the paleo-denudation rates that affected the Têt sediments, which were 2 to 3 times lower than their and our current rates for the Pliocene sediments. This result can be interpreted as either the result of different climatic conditions that influenced the weathering rate or a reduction in the incision and denudation because of the abrupt rise of the base level. Thus, the incision process in the Conflent could have been modulated by Pliocene eustatism and an aggradation phase may have occurred during the base-level upturns. Finally, the Cerdagne and Conflent faults, similar to those of the Têt, were sealed by the Messinian erosion surface (MES) and were exhumed by denudation processes (Delcaillau et al., 2004). Thus, the tectonic activity likely persisted until the beginning of the Pliocene but did not continue beyond this point. According to this scenario, the near cessation of tectonic activity could explain the overall slowdown in the evolution of the valley. 
However, some authors have denied this hypothesis (e.g., Briais et al., 1990) because the

825

826

827

828

829

830

831

832

833

834

835

836

837

838

839

840

841

842

843

844

845

846

847

848

849

850

851

852

853

854

855

856

857

858 extension phase continued and these tectonic events were active during the Quaternary. These authors argued that the eustatic control would not have been negligible during this period because of the MSC and subsequent eustatic variations. We cannot currently determine which factors predominantly controlled the incision over this period, so straightforwardly linking incision and uplift rates is impossible.

Finally, staggered horizontal galleries that developed during several stages were often linked to the deepening of the valleys. By deduction, the highest level would correspond to the initial position of the river, while the levels close to the river would be contemporaneous with the most recent phases of valley deepening. Although this per descensum scheme has long been systematically applied to interpret the staggering of the networks, this scheme has been invalidated in another context (Ardèche) by Mocochain et al. (2009), who proposed an inverse chronology, namely, a per ascensum staging of the galleries. This per ascensum scenario was based on morphological arguments and, in particular, the peculiar morphology of wells that connected these galleries, which evidenced ascending water circulation in response to base level uprising after the MSC. This type of morphology seems to be absent in the cavities of the Têt canyon (except in the Fuilla-Canalettes network and a well between two galleries in a cave in the Badebany massif), the galleries of which are ample subterranean crossings of the river. This hypothesis thus seems irrelevant in our case to explain the variability of the ratios since the Messinian. However, these observations fall within the current knowledge framework. As already mentioned, we do not know the nature of the networks at the time of their formation because of their subsequent dismantling and/or obstruction.

\subsection{Reliability of the derived paleodenudation rates}

With the exception of three samples from the lowest stage, namely, the En Gorner's network, which were clasts and not sands, all the samples' concentrations produced maximum paleodenudation rates that were lower than $150 \mathrm{~cm} / \mathrm{ka}$ (Table 6; Figure 8), similar to those that are characteristic of cratonic zones and to those that were determined in the French Massif Central, which is a component of the Hercynian orogenic belt (Olivetti et al., 2016). Such low maximum paleodenudation rates imply that large initial ${ }^{10} \mathrm{Be},{ }^{26} \mathrm{Al}$ and ${ }^{21} \mathrm{Ne}$ concentrations accumulated within the quartz minerals of the samples, which in turn implies a long pre-exposure duration at the surface. This finding could support the stability of the massive sources before the initiation of the incision. The maximum paleodenudation rate from the cosmogenic nuclide concentrations in the Roc Campagna alluvium suggests a potential small flat surface that was incised during the Burdigalian. This finding is consistent with the 
thermochronology data from the Carlit area but not with those from the Canigou and Carança massifs (Maurel et al., 2008).

This would mean that the sediments collected in the cavities come from watersheds that have been relatively stable since about $25 \mathrm{Ma}$, which is not contradictory with the thermochronological data of Maurel et al. (2008) and Gunnell et al. (2009). The presence of Highly-Elevated Low-Relief surfaces can thus partly explain these findings.

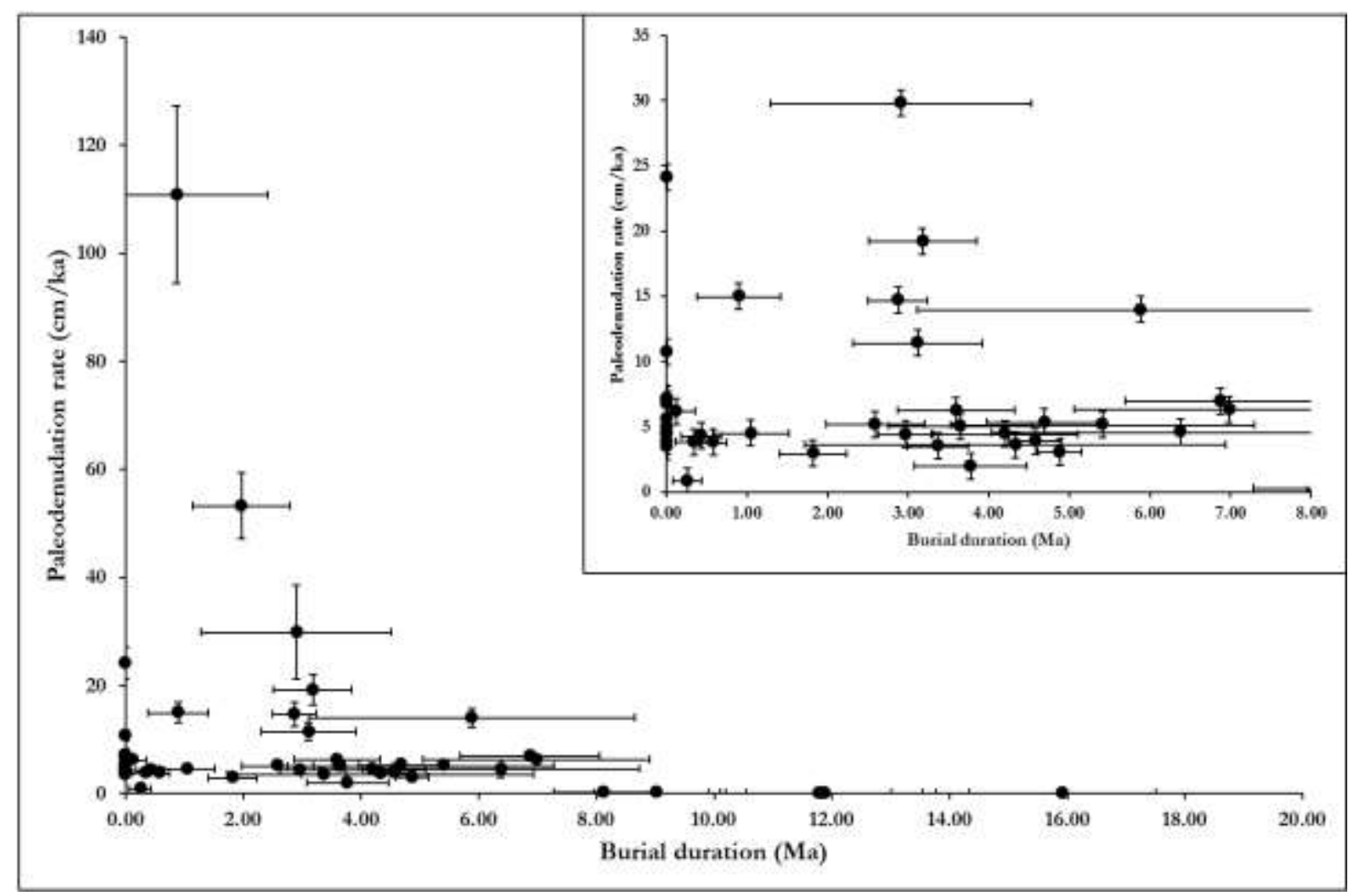

Figure 8: Paleodenudation rates as a function of time (see Table 6). Most of the data are from the Pliocene to the present. No trend is clearly visible.

The thermochronological data acquired for the most part in the west and southwest of the study area document denudations of the order of several hundred meters for the end of the Eo-Oligocene compression period (e.g., Sinclair et al. 2005, Gibson et al., 2007, Jolivet et al., 2007). The thick deposits in the central piedmonts testify to this intense exhumation activity before 30 to $25 \mathrm{Ma}$, that is during the Eocene and the Oligocene (Poudingues de Palassou in the North and Berga in the South). However, the acquired data do not agree with such high paleodenudation rates and are incompatible with 1 to $2 \mathrm{~km}$ thick continental detrital deposits in the Roussillon basin between 23 and $16 \mathrm{Ma}$. It should also be noted that at least 500 meters thick deposits have been accumulated in the Conflent and Cerdagne basins between 12 and 6

877 Ma (e.g., Calvet, 1996). Such discrepancies have already been observed, but to a lesser extent, 878 by Molliex et al. (2016) who compared the paleodenudation rates derived from the Roussillon 879 basin deposits in the piedmont relative to those derived from continental shelf deposits. They 
propose that this may result from significantly different time periods over which the

881

882

883

884

885

886

887

888

889

890

891

892

893

894

895

896

897

898

899

900

901

902

903

904

905

906

907

908

909

910

911

912

913

914

denudation processes are integrated. Regarding the ${ }^{10} \mathrm{Be}$ and ${ }^{26} \mathrm{Al}$ cosmogenic nuclides which integrate over several hundred years, the stochastic events are averaged, and are not, or hardly, perceivable in the obtained records. This assertion is all the more true for ${ }^{21} \mathrm{Ne}$ which integrates over a much longer time period and accumulates at each exposure episode.

Therefore, although, due to the steady-state assumption, the denudation rates calculated from cosmogenic nuclide concentrations are theoretically maximum denudation rates, they may in fact, due to the occurrence of potential massive stochastic events, be geologically minimum denudation rates.

Regarding the significantly higher maximum paleodenudation rates calculated from the concentrations of the En Gorner network samples, no relationship existed between the maximum paleodenudation rates and the particle sizes, so our only possible explanation is the origin of the clasts. Indeed, similar lithologies were found at very remote locations in the watershed. Therefore, we could not discriminate whether the pebbles originated from proximal or distal points in the catchment or whether these rocks were produced in more sloping areas, during particular climatic events, or during stochastic events, among others. Moreover, the high paleo-denudation rates that were determined in this cavity may not be accurate because of potential inheritance of the measured ${ }^{26} \mathrm{Al} /{ }^{10} \mathrm{Be}$ ratios at the lower levels from the Escaro Formation.

Previous paleodenudation rates from TCN concentrations in the Pyrenees were mainly associated with studies of alluvial terraces in piedmonts (Stange et al., 2012, 2014; Delmas et al., 2015; Nivière et al, 2016; Mouchené et al., 2017), alluvial deposits from large catchments (Molliex et al., 2016), or subglacial and supraglacial ridgetop deposits (Crest et al., 2017). Some preliminary dating of alluvial cave sediments (Genti, 2015) are also available. For the alluvial terraces from the Pleistocene and Holocene, the denudation rates that were derived by these authors were predominantly lower than $20 \mathrm{~cm} / \mathrm{ka}$. The rates in the glacial context were also reported to be relatively low, including in the Carlit massif, one of the sources of the studied sediments (Delmas et al., 2009), and river fluvial deposits that were collected from the Têt River watershed produced comparable denudation rates to those in the French Massif Central and the plains (Molliex et al., 2016). Finally, all these published results, which enabled us to distinguish potential paleodenudation gradients between the eastern and western sections of the chain and between the southern and northern piedmonts, are consistent with those in this study.

\section{Conclusions}


Burial durations from ${ }^{26} \mathrm{Al} /{ }^{10} \mathrm{Be}$ and/or ${ }^{10} \mathrm{Be} /{ }^{21} \mathrm{Ne}$ ratios that were measured in alluvial

916 deposits from 11 caves documented a Têt valley incision that occurred in successive stages.

917 The incision likely began during the Early Miocene, probably before 168 Ma, from poorly

918 incised post-orogenic surfaces possibly because of an isostatic rebound that compensated for

919 lithospheric thinning from the opening of the Gulf of Lion. Although we could not determine

920 whether this event was caused by the opening of the Conflent graben and/or a drastic

921 lowering of the global base level around the Langhian - Serravallian transition ( 11 Ma),

922 acceleration from $\sim 20 \mathrm{~m} / \mathrm{Ma}$ to $\sim 80-160 \mathrm{~m} / \mathrm{Ma}$ of the Têt valley entrenchment was evidenced.

923 The obtained record from the Messinian to the present questioned the methodological 924 assumptions rather than facilitating relatively straightforward geomorphological 925 interpretations and demonstrated the need for a reasoned sampling. This necessity to be cautious regarding the origin and history of the deposits when sampling within cavities (Laureano et al., 2016) is evidenced by both the analyses of riverbed samples and the dating 928 of the Escaro Formation to the Pliocene (at this location). The latter undoubtedly must be 929 further investigated, but this new dataset about this Escaro formation, if true, may have 930 important consequences regarding the global evolution of the massif. This assertion is most 931 likely valid no matter the period (and therefore the level of the karstic system), the relics, or 932 the investigated events, assuming the possible presence of pre-buried material upstream.

Finally, this work demonstrated the scope of the use of cosmogenic ${ }^{21} \mathrm{Ne}$ combined with the determination of ${ }^{10} \mathrm{Be}$ and ${ }^{26} \mathrm{Al}$ concentrations in karstic deposits to determine the abandonment age of karst systems, notably for the oldest systems via the use of the ${ }^{10} \mathrm{Be}-{ }^{21} \mathrm{Ne}$ paired nuclides.

Acknowledgments

We thank the financial and technical support of the BRGM, within the framework of the RGF - Pyrenées program. We also thank Mary Ford, Philippe Audra, Stéphane Jaillet,

942 Gemma de Vicente i Bosch, Philippe Vernant, Patrick Sorriaux and Yanni Gunnell for fruitful 943 discussions during meetings. We thank Marc Calvet for our discussions about previous 944 versions of this manuscript and fieldwork assistance. We are especially grateful to Gabriel 945 Hez, Jean-Louis Perez and Stéphane Jaillet for their fieldwork assistance and the invaluable 946 discussions that resulted, as well as the sharing of topographic data. We sincerely thank V. 947 Regard and H. Wittmann for their constructive reviews that improved the quality of this 948 manuscript. The ASTER AMS national facility (CEREGE, Aix-en-Provence) is supported by 
949

950

951

952

953

954

955

956

957

958

959

960

961

962

963

964

965

966

967

968

969

970

971

972

973

974

975

976

977

978

979

980

the INSU/CNRS, the ANR through the "Projets thématiques d'excellence" program for the "Equipements d'excellence" ASTER-CEREGE action and IRD.

\section{References}

Arnold, M., Merchel, S., Bourles, D.L., Braucher, R., Benedetti, L., Finkel, R.C., Aumaître, G., Gottdang, A., Klein, M., 2010. The French accelerator mass spectrometry facility ASTER: Improved performance and developments. Nucl. Instr. Methods Phys. Res. B, 268, 19541959. https://doi.org/10.1016/j.nimb.2010.02.107

Audra, P. 1994. Karsts alpins - Genèse de grands réseaux souterrains. Karstologia Mémoires, 5. In French

Audra P., Palmer A.N. 2013. The Vertical Dimension of Karst: Controls of Vertical Cave Pattern. In: John F. Shroder (Editor-in-chief), Frumkin, A. (Volume Editor) Treatise on Geomorphology, Vol 6, Karst Geomorphology, San Diego, Academic Press, p. 186-206. https://doi.org/10.1016/B978-0-12-374739-6.00098-1

Babault, J., van den Driessche, J., Bonnet, S., 2005. Origin of the highly elevated Pyrenean peneplain. Tectonics, 24, TC2010. https://doi.org/10.1029/2004TC001697

Balco, G., and Shuster, D.L. 2009. ${ }^{26} \mathrm{Al}-{ }^{10} \mathrm{Be}-{ }^{21} \mathrm{Ne}$ burial dating. Earth and Planetary Science Letters, 286(3-4), 570-575. https://doi.org/10.1016/j.eps1.2009.07.025

Baudelot, S., Crouzel, F. 1974. La faune burdigalienne des gisements d'Espira-du-Conflent (Pyrénées-Orientales). Bull. Soc. Hist. Nat. Toulouse, 110(3-4), 311-326.

Borchers, B., Marrero, S., Balco, G., Caffee, M., Goehring, B., Lifton, N., Nishiizumi, K., Phillips, F., Schaefer, J., and Stone, J. 2016. Geological calibration of spallation production rates in the CRONUS-Earth project. Quaternary Geochronology, 31, 188-198. https://doi.org/10.1016/j.quageo.2015.01.009

Bosch, G.V., Van Den Driessche, J., Babault, J., Robert, A., Carballo, A., Le Carlier, C., Loget, N., Prognon, C., Wyns, R. and Baudin, T. 2016. Peneplanation and lithosphere dynamics in the Pyrenees. Comptes Rendus Geoscience, 348, 194-202. https://doi.org/10.1016/j.crte.2015.08.005

Braucher, R., Merchel, S., Borgomano, J., Bourlès, D.L., 2011. Production of cosmogenic radionuclides at great depth: a multi element approach. Earth Planet. Sci. Lett. 309, 1-9. https://doi.org/10.1016/j.eps1.2011.06.036 
981

982

983

984

985

986

987

988

989

990

991

992

993

994

995

996

997

998

999

1000

1001

1002

1003

1004

1005

1006

1007

1008

1009

1010

1011

Briais, A., Armijo, R.., Winter, T., Tapponnier, P. and Herbecq, A. 1990. Morphological evidence for Quaternary normal faulting and seismic hazard in the eastern Pyrénées. Annales tectonicae, IV, 19-42

Brown, E.T., Edmond, J.M., Raisbeck, G.M., Yiou, F., Kurz, M.D., Brook, E.J., 1991, Examination of surface exposure ages of Antarctic moraines using in situ produced ${ }^{10} \mathrm{Be}$ and ${ }^{26}$ Al. Geochim. Cosmochim. Acta 55, 2269-2283. https://doi.org/10.1016/00167037(91)90103-C

Brown, E.T., Stallard, R.F., Larsen, M.C., Raisbeck, G.M., Yiou, F. 1995. Denudation rates determined from the accumulation of in situ produced ${ }^{10} \mathrm{Be}$ in the Luquillo Experimental forest, Puerto Rico. Earth and Planetary Science Letters. 129, 193-202. https://doi.org/10.1016/0012-821X(94)00249-X

Calvet M. 1996. Morphogenèse d'une montagne méditerranéenne : les Pyrénées orientales. Documents du BRGM, Orléans, n² 255, 3 vol., 1177 p.

Calvet, M., Gunnell, Y., Braucher, R., Hez, G., Bourles, D., Guillou, V., Delmas, M.\& ASTER Team. 2015. Cave levels as proxies for measuring post-orogenic uplift: Evidence from cosmogenic dating of alluvium-filled caves in the French Pyrenees. Geomorphology, 246, 617-633. https://doi.org/10.1016/j.geomorph.2015.07.013

Chevrot S., Sylvander M., Delouis B. 2011. A preliminary catalog of moment tensors for the Pyrenees. Tectonophysics, 510, 239-251. https://doi.org/10.1016/j.tecto.2011.07.011

Chevrot, S., Villaseñor, A. et Sylvander, M. 2014. High resolution imaging of the Pyrenees and Massif Central from the data of the PYROPE and IBERARRAY portable array deployments. Journal of Geophysical Research, 119(8), 6399-6420. https://doi.org/ 10.1002/2014JB010953

Chmeleff, J., von Blanckenburg, F., Kossert, K., Jakob, J, 2010. Determination of the ${ }^{10} \mathrm{Be}$ half-life by multicollector ICP-MS and liquid scintillation counting. Nucl. Instr. Methods Phys. Res. B. 268, 192-199. https://doi.org/10.1016/j.nimb.2009.09.012

Choukroune, P. 1992. Tectonic evolution of the Pyrenees, Ann. Rev. Earth Planet. Sci., 20, 143

Clauzon, G. 1982. Le canyon messinien du Rhône : une preuve décisive du « dessicated deep basin model » (Hsü, Cita and Ryan, 1973). Bulletin de la Société Géologique de France, 24, 231-246. 
Clauzon, G., Rubino, J.L., Savoye, B. 1995. Marine Pliocene Gilbert-type fan deltas along the

1013 French Mediterranean coast. A typical infill feature of preexisting subaerial Messinian

1014 canyons. IAS-16 ${ }^{\text {th }}$ egional Meeting of Sedimentology, Field Trip Guide Book, ASF Ed., 1015 vol.23, Paris, pp. 145-222.

1016 Clauzon, G., Le Strat, P., Duvail, C., Do Couto, D., Suc, J.-P., Molliex, S., Bache, F., Besson, 1017 D., Lindsay, E.H., Opdyke, N.D., Rubino, J.-P., Speranta-Maria Popescu, S.-P., Haq, B.U. 1018 and Gorini, C. 2015. The Roussillon Basin (S. France): A case-study to distinguish local and 1019 regional events between 6 and 3 Ma. Marine and Petroleum Geology, 66, 18-40. 1020 https://doi.org/10.1016/j.marpetgeo.2015.03.012

1021 Codilean, A.T., Fenton, C.R., Fabel, D., Bishop, P., Xu, S., 2014. Discordance between 1022 cosmogenic nuclide concentrations in amalgamated sands and individual fluvial pebbles in an 1023 arid zone catchment. Quaternary Geochronology, 19, 173-180. https://doi.org/10.1016/j.quageo.2012.04.007

Debals, B. 2000. Mise au point sur la chronostratigraphie des dépôts alluviaux quaternaires de la plaine du Roussillon : exemple de la vallée de la Têt (France). Quaternaire, 1, 31-39. https://doi.org/10.3406/quate.2000.1653

Delcaillau, B., Carozza, J.-M. and Font, M. 2004. The northern segment of the Têt Fault (Pyrenees-Orientales): Neogene evolution and geomorphic implications. Bulletin de la Société. Géologique de France, 175(3), 257-272. https://doi.org/10.2113/175.3.257

1031 Delmas, M., Braucher, R., Gunnell, Y., Guillou, V., Calvet, M., Bourlès, D.L. and ASTER 1032 Team. 2015. Constraints on Pleistocene glaciofluvial terrace age and related soil 1033 chronosequence features from vertical ${ }^{10} \mathrm{Be}$ profiles in the Ariège River catchment (Pyrenees, 1034 France). Global and Planetary Change, 132, 39-53. 1035 https://doi.org/10.1016/j.gloplacha.2015.06.011

1036 Depéret, C. 1895. Aperçu de la structure générale et l'histoire de la formation de la vallée du 1037 Rhône. Annales de Géographie, 4, 432-452.

1038 Dunai, T. J. 2010. Cosmogenic Nuclides, Principles, Concepts and Applications in the Earth 1039 Surface Sciences. Cambridge University Press, 198 pages; ISBN-13: 9780521873802

1040 Engel, W. 1984. Migration of folding and flysch sedimentation on the southern flank of the 1041 Variscan belt (Montagne Noire, Mouthoumet massif, Pyrenees). Z. dt. Geol. Ges., 135, 2791042292. 
1043 Fitzgerald, P.G., Muñoz, J.A., Coney, P.J., Baldwin, S.L. 1999. Asymmetric exhumation

1044 across the Pyrenean orogen: implications for the tectonic evolution of a collisional orogen.

1045 Earth and Planetary Science Letters, 173, 157-170. https://doi.org/10.1016/S0012$1046 \quad 821 X(99) 00225-3$

1047 Ford, M., Hemmer, L., Vacherat, A., Gallagher, K and Christophoul, F. 2015. Retro-wedge

1048 foreland basin evolution along the ECORS line, eastern Pyrenees, France. Journal of 1049 Geological Society, 173, 419-437. https://doi.org/10.1144/jgs2015-129

1050 Gautier, F., Clauzon, G., Suc, J.-P., Cravatte, J., Violanti, D. 1994. Âge et durée de la crise de 1051 salinité messinienne. Comptes-Rendus de l'Académie des Sciences de Paris, 318(II), 110310521109.

1053 Genti, M. 2015. Impact des processus de surface sur la déformation actuelle des Pyrénées et 1054 des Alpes. Thèse de doctorat, Université de Montpellier, France, 255 pp. In French

1055 Gibson, M., Sinclair, H.D., Lynn, G.J. et Stuart, F.M. 2007. Late- to post-orogenic 1056 exhumation of the Central Pyrenees revealed through combined thermochronological data and 1057 modeling. Basin Redearch, 19, 323-334

1058 Godard, V., Bourlès, D. L., Spinabella, F., Burbank, D. W., Bookhagen, B., Fisher, G. B., 1059 Moulin, A. \& Léanni, L. 2014. Dominance of tectonics over climate in Himalayan 1060 denudation. Geology, G35342-1. https://doi.org/10.1130/G35342.1

1061 Granger, D.E., Kirchner, J.W., Finkel, R.C. 1997. Quaternary downcutting rate of the New

1062 River, Virginia, measured from differential decay of cosmogenic ${ }^{26} \mathrm{Al}$ and ${ }^{10} \mathrm{Be}$ in cave1063 deposited alluvium. Geology, 25, 107-110. . https://doi.org/10.1130/0091-7613(1997) 1064 025<0107:QDROTN>2.3.CO;2

1065 Guitard, G., Laumonier, A., Autran, A., Bandet, Y. and Berger, G.M. 1998. Notice explicative 1066 de la carte géologique de Prades (1095) au 1/50000 ${ }^{\text {ème }}$. BRGM - Service Géologique 1067 National, Ministère de l'Economie, des Finances et de l'Industrie. Editions du BRGM, pp. 1068198

1069 Gunnell, Y. and Calvet, M. 2006. Comment on «Origin of the highly elevated Pyrenean 1070 peneplain », by J. Babault et al. Tectonics, 25, TC3003. 1071 https://doi.org/10.1029/2004TC001697

1072 Gunnell Y., Zeyen H., Calvet M. 2008. Geophysical evidence of a missing lithospheric root 1073 beneath the Eastern Pyrenees: consequences for post-orogenic uplift and associated 
1076 Gunnell, Y., Calvet, M., Brichau, S., Carter, A., Aguilar, J.P. et Zeyen, H. 2009. Low long1077 term erosion rates in high-energy mountain belts: Insights from thermo- and biochronology in 1078 the Eastern Pyrenees. Earth and Planetary Science Letters, 278, 208-218

1079 Haq, B.U., Hardenbol, J, Vail, P.R., 1987. Chronology of Fluctuating Sea Levels Since the Triassic. Science, 235, 1156-1167. https://doi.org/10.1126/science.235.4793.1156

1081 Häuselmann P., Granger D.E. 2005. Dating of caves by cosmogenic nuclides: method, 1082 possibilities, and the Siebenhengste example (Switzerland). Acta Carsologica, 34(1), 93-100.

1083 Hez, G. 2015. Un remarquable enregistreur de l'incision de la vallée de la Têt : Le karst étagé 1084 des gorges de Villefranche de Conflent Pyrénées-Orientales - France. Mémoire de M2, 1085 Université de Savoie Mont-Blanc, 117 pp. In French

1086 Hez, G., Jaillet, S., Calvet, M., and Delannoy, J.-J. 2015. Un enregistreur exceptionnel de 1087 l'incision de la vallée de la Têt : le karst de Villefranche-de-Conflent (Pyrénées-Orientales), 1088 France. Karstologia, 65, 9-32. In French

1089 Honda, M., Zhang, X., Phillips, D., Hamilton, D., Deerberg, M., Schwieters, J.B. 2015. 1090 Redetermination of the ${ }^{21} \mathrm{Ne}$ relative abundance of the atmosphere, using a high resolution, 1091 multi-collector noble gas mass spectrometer (HELIX-MC Plus). International Journal of Mass Spectrometry, 387, 1-7. https://doi.org/10.1016/j.ijms.2015.05.012

1093 Hsü, K.J., Cita, M.B., Ryan, W.B.F. 1973. The origin oft he Mediterranean evaporates. In: 1094 Ryan, W.B.F., Hsü, K.J., Cita, M.B., Dumitrica, P., Lort, J.M., Maync, W., Nesteroff, W.D., 1095 Pautot, G., Stradner, H., Wezel, F.C., Kaneps, A.G. (Eds), Initial Reports of the Deep Sea 1096 Drilling Project, vol.13, U.S. Government Printing Office, Washington, D.C., pp. 1203-1231.

1097 Jolivet, M., Labaume, P., Monié, P., Brunel, M., Arnaud, N. et Campani, M. 2007. 1098 Thermochronology constraints for the propagation sequence of the southe Pyrenean basement 1099 thrust system (France-Spain). Tectonics, 26, TC5007

1100 Keen-Zebert, A., Granger, D.E., Paces, J.B., Hudson, M.R., and Bitting, C. 2016. Combined 1101 use of cosmogenic nuclide, U-series disequilibrium, paleomagnetism, and optically stimulated 1102 luminescence within Fitton Cave to evaluate the landscape evolution of the Buffalo National 1103 River, Arkansas (abs.): Geological Society of America Abstracts with Programs, 48(7), doi: 1104 10.1130/abs/2016AM-285655. 
1105

1106

1107

1108

1109

1110

1111

1112

1113

1114

1115

1116

1117

1118

1119

1120

1121

1122

1123

1124

1125

1126

1127

1128

1129

1130

1131

1132

1133

1134

1135

1136

Kober, F., Ivy-Ochs, S., Schlunegger, F., Baur, H., Kubik, P.W., Wieler, R. 2007. Denudation rates and a topography-driven rainfall threshold in northern Chile: Multiple cosmogenic nuclide data and sediment yield budgets. Geomorphology, 83, 97-120.

Korschinek, G., Bergmaier, A., Faestermann, T., Gerstmann, U.C., Knie, K., Rugel, G.,Wallner, A., Dillmann, I., Dollinger, G., von Gostomski, Lierse Ch., Kossert, K., Maitia,M., Poutivtsev, M., Remmert, A., 2010. A new value for the half-life of ${ }^{10} \mathrm{Be}$ by Heavy-Ion Elastic Recoil Detection and liquid scintillation counting. Nucl. Instr. Methods Phys. Res. B, 268, 187-191. https://doi.org/10.1016/j.nimb.2009.09.020

Lagabrielle, Y., Labaume, P. and de Saint Blanquat, M. 2010. Mantle exhumation, crustal denudation, and gravity tectonics during Cretaceous rifting in the Pyrenean realm (SW Europe): Insights from the geological setting of the lherzolite bodies. Tectonics, 29(4), TC4012, doi:10.1029/2009TC002588.

Laumonier, B. et coord., 1996. Cambro-Ordovicien, in Barnolas A., Chiron J.C.: "Synthèse géologique et géophysique des Pyrénées, ” vol. 1, éditions BRGM-ITGE, pp. 157-209.

Laumonier, B. 2015. Les Pyrénées alpines sud-orientales (France, Espagne) - essai de synthèse. Rev. Géologie Pyrénéenne, 2, 1-44.

Laureano, F.V., Karmann, I., Granger, D.E., Auler, A.S., Almeida, R.P., Cruz, F.W., Strícks, N.M., and Novello, V.F. 2016. Two million years of river and cave aggradation in NE Brazil: Implications for speleogenesis and landscape evolution. Geomorphology, 273, 63-77. https://doi.org/10.1016/j.geomorph.2016.08.009

Loget, N., van den Driessche, J. and Davy, P., 2005. How did the Messinian salinity crisis end? Terra Nova, 17, 414-419. https://doi.org/10.1111/j.1365-3121.2005.00627.x

Loget, N., Van Den Driessche, J. 2009. Wave train model for knickpoint migration. Geomorphology, 106, 376-382.

Loget, N., Davy, P., van den Driessche, J. 2006. Mesoscale fluvial erosion parameters deduced from modeling the Mediterranean sea level drop during the Messinian (late Miocene). Journal of Geophysical Research, 111, F03005. https://doi.org/10.1029/2005JF000387.

Martin, L.C.P, Blard, P.-H., Balco, G., Lavé, J., Delunel, R., Lifton, N., Laurent, V. 2017. The CREp program and the ICE-D production rate calibration database: A fully parameterizable and updated online tool to compute cosmic-ray exposure ages. Quaternary Geochronology, 38, 25-49. https://doi.org/10.1016/j.quageo.2016.11.006 
1137 Mauffret, A., de Grossouvre, B. D., Dos Reis, A. T., Gorini, C., \& Nercessian, A. (2001).

1138 Structural geometry in the eastern Pyrenees and western Gulf of Lion (Western 1139 Mediterranean). Journal of Structural Geology,23(11), 1701-1726.

1140 https://doi.org/10.1016/S0191-8141(01)00025-6

1141 Maurel, O., Monié, P., Pik, R., Arnaud, N., Brunel, M., Jolivet, M. 2008. The Meso-Cenozoic 1142 thermo-tectonic evolution of the Eastern Pyrenees: an ${ }^{40} \mathrm{Ar} /{ }^{39} \mathrm{Ar}$ fission track and $(\mathrm{U}-\mathrm{Th}) / \mathrm{He}$ 1143 thermochronological study of the Canigou and Mont-Louis massifs. International Journal of 1144 Earth Science, 97, 565-584. https://doi.org/10.1007/s00531-007-0179-x

1145 McPhillips, D., Hoke, G.D., Liu-Zeng, J., Bierman, P.R., Rood, D.H., and Niedermann, S. 1146 2016. Dating the incision of the Yantze River gorge at the First Bend using three-nuclide 1147 burial ages. Geophysical Research Letters, 43(1), 101-110. https://doi.org/ $1148 \quad 10.1002 / 2015$ GL066780

1149 Merchel, S., Herpers, U., 1999. An update on radiochemical separation techniques for the 1150 determination of long-lived radionuclides via accelerator mass spectrometry. Radiochim. Acta $115184,215-219$.

1152 Merchel, S., Bremser, W., 2004. First international 26Al interlaboratory comparison - Part I.

1153 Nuclear Instrumentation Methods in Physics Research, Section B: Beam Interactions with 1154 Materials and Atoms. 223-224, pp. 393-400. https://doi.org/10.1016/j.nimb.2004.04.076

1155 Merchel, S, Arnold, M., Aumaître, G., Benedetti,L., Bourlès, D.L., Braucher, R., Alfimov, V., 1156 Freeman, S.P.H.T, and Wallner, A. 2008. Towards more precise ${ }^{10} \mathrm{Be}$ and ${ }^{36} \mathrm{Cl}$ data from 1157 measurements at the $10^{-14}$ level: Influence of sample preparation. Nuclear Instruments and 1158 Methods in Physics Research B, 266, 4921-4926. https://doi.org/10.1016/j.nimb.2008.07.031

1159 Mocochain, L., Audra, P., Clauzon, G., Bellier, O., Bigot, J.-Y., Parize, O., Monteil, P., 2009. 1160 The effect of river dynamics induced by the Messinian Salinity Crisis on karst landscape and 1161 caves: Example of the Lower Ardèche river (mid Rhône valley). Geomorphology, 106, 46-61. 1162 https://doi.org/10.1016/j.geomorph.2008.09.021

1163 Molliex, S., Rabineau, M., Leroux, E, Bourlès, D., Authemayou, C., Aslanian, D., Chauvet, 1164 F., Civet, F. and Jouët, G. 2016. Multi-approach quantification of denudation rates in the Gulf 1165 of Lion source-to-sink system (SE France). Earth and Planetary Science Letters, 444, 1011166 115. https://doi.org/10.1016/j.epsl.2016.03.043

1167 Molnar, P., and England, P. 1990. Late Cenozoic uplift of mountain ranges and global climate 1168 change: chicken or egg?, Nature, 346, 29-34. https://doi.org/10.1038/346029a0 
Monod, B., Regard, V., Carcone, J., Wyns, R. and Christophoul, F. 2016. Postorogenic planar

1170 palaeosurfaces of the central Pyrenees: Weathering and neotectonic records. Comptes Rendus

1171 Geoscience, 348(3-4), 184-193, doi:10.1016/j.crte.2015.09.005

1172 Mouchené, M., van der Beek, P., Mouthereau, F. and Carcaillet, J. 2017. Controls on

1173 Quaternary incision of the Northern Pyrenean foreland: Chronological and geomorphological

1174 constraints from the Lannemezan megafan, SW France. Geomorphology, 281, 78-93, 1175 doi:10.1016/j.geomorph.2016.12.027

1176 Mouchené, M., van der Beek, P., Mouthereau, F., Carcaillet, J. 2017. Controls on Quaternary

1177 incision of the Northern Pyrenean foreland: Chronological and geomorphological constraints

1178 from the Lannemezan megafan, SW France. Geormophology, 281, 78-93.

1179 https://doi.org/10.1016/j.geomorph.2016.12.027

1180 Niedermann, S. 2002. Cosmic-ray-produced noble gases in terrestrial rocks: dating tools for 1181 surface processes. Rev. Mineral. Geochem. 47, 731-784.

1182 https://doi.org/10.2138/rmg.2002.47.16

1183 Nishiizumi, K.; Imamura, M.; Caffee, M.W.; Southon, J.R.; Finkel, R.C.; McAninch, J. 2007.

1184 Absolute calibration of ${ }^{10}$ Be AMS standards. Nucl. Instrum. Methods Phys. Res. Sect. B, 258,

1185 403-413. https://doi.org/10.1016/j.nimb.2007.01.297

1186 Nivière, B., Lacan, P., Regard, V., Delmas, M., Calvet, M., Huyghe, D., Roddaz, B., 2016.

1187 Evolution of the Late Pleistocene Aspe River (Western Pyrenees, France). Signature of

1188 climatic events and active tectonics. Comptes Rendus Geoscience. doi:

1189 10.1016/j.crte.2015.07.003

1190 Norris, T. L., A. J. Gancarz, D. J. Rokop, and K. W. Thomas (1983), Half-life of ${ }^{26}$ Al, J.

1191 Geophys. Res., 88(S01), B331-B333, doi:10.1029/JB088iS01p0B331

1192 Oele, E., Sluiter, W.J., and Pannekoek, A.J. 1963. Tertiary and Quaternary sedimentation in 1193 the Conflent, an intramontane rift-valley in the eastern Pyrenees. Leids geol. Meded. 28, $297-$ 1194319.

1195 Olivetti, V., Godard, V., Bellier, O., ASTER Team. 2016. Cenozoic rejuvenation events of 1196 Massif Central topography (France): Insights from cosmogenic denudation rates and 1197 river profiles. Earth and Planetary Science Letters, 444, 179-191. 1198 https://doi.org/10.1016/j.eps1.2016.03.049 
1199 Ortuño, M., Martí, A., Martín-Closas, C., Jiménez-Moreno, G., Martinetto, E. and Santanach, 1200 P. 2013. Palaeoenvironments of the Late Miocene Prüedo Basin: implications for the uplift of 1201 the Central Pyrenees. J. Geol. Soc., 170(1), 79-92, doi:10.1144/jgs2011-121

1202 Paces, J.B., Hudson, M.R., Hudson, A.M., Turner, K.J., Bitting, CJ., and Sugano, L.L. 2017. 1203 Isotopic constraints on Middle Pleistocene cave evolution, paleohydrologic flow, and 1204 environmental conditions from Fitton Cave speleothems, Buffalo National River, Arkansas. (abs.): In: Kuniansky, E.L., and Spangler, L.E., eds., 2017, U.S. Geological Survey Karst Interest Group Proceedings, San Antonio, Texas, May 16-18, 2017: U.S. Geological Survey Scientific Investigations Report 2017-5023, 245 p., http://doi.org/10.3133/sir20175023.

1208 Palmer A.N. 2007. Cave Geology, Cave Books, Cave Research Foundation, Dayton, 454 p.

1209 Pannekoek, A.J., 1935. Évolution du bassin de la Têt pendant le Néogène. Geogr. Geol. Mad. 1210 Rijkuniv. Utrecht 10, p. 72.

1211 Pérez-Asensio, J.N., Aguirre, J., Jiménez-Moreno, G., Schmiedl, G. and Civis J. 2013. 1212 Glacioeustatic control on the origin and cessation of the Messinian salinity crisis. Global and 1213 Planetary Change, 111, 1-8. https://doi.org/10.1016/j.gloplacha.2013.08.008

1214 Reiners, P.W., Ehlers, T. a, Mitchell, S.G., Montgomery, D.R., 2003. Coupled spatial 1215 variations in precipitation and long-term erosion rates across the Washington Cascades. 1216 Nature 426, 645-7. https://doi.org/10.1038/nature02111

1217 Sinclair, H.D., Gibson, M., Naylor, M. et Morris, R.G. 2005. Asymmetric growth of the 1218 Pyrenees revealed through measurement and modeling of orogenic fluxes. American Journal 1219 of Science, 305, 369-406

1220 Stange, K.M., van Balen, R.T., Kasse, C., Vandenberghe J., Carcaillet, J. 2014. Linking 1221 morphology across glaciofluvial interface: $\mathrm{A}{ }^{10} \mathrm{Be}$ supported chronology of glacier advanced 1222 and terrace formation in the Garonne River, northern Pyrenees, France. Geomorphology, 207, 1223 71-95. https://doi.org/10.1016/j.geomorph.2013.10.028

1224 Stange, K.M., van Balen, R.T., Carcaillet, J. \& Vandenberghe J. 2013. Terrace staircase 1225 development in the Southern Pyrenees Foreland: Inferences from ${ }^{10} \mathrm{Be}$ terrace exposure ages 1226 at the Segre River. Global and Planetary Change, 101, 97-112. 1227 https://doi.org/10.1016/j.gloplacha.2012.12.007

1228 Stange, K.M., van Balen, R.T., Vandenberghe J., Peña, J.-L. \& Sancho, C. 2012. External 1229 controls on Quaternary fluvial incision and terrace formation at the Segre River, Southern 1230 Pyrenees. Tectonophysics, 602, 316-331. https://doi.org/10.1016/j.tecto.2012.10.033 
Stone, J.O., 2000. Air pressure and cosmogenic isotope production. Journ. Geophys. Res. 105,

1233 Suc, J.-P., Clauzon, G., Cravatte, J., Gautier, F., Violenti, D. 1994. Âge et durée de la crise de 1234 salinité messinienne. Comptes Rendus de l'Académie des Sciences, Paris, Série II, 318, 110312351109.

1236 Tassy A., Mocochain L., Bellier O., Braucher R., Gattacceca J., Bourlès D. 2013. Coupling 1237 cosmogenic dating and magnetostratigraphy to constrain the chronological evolution of peri1238 Mediterranean karsts during the Messinian and the Pliocene: Example of Ardèche Valley, 1239 Southern $\quad$ France. $\quad$ Geomorphology, $\quad 189, \quad 81-92$. 1240 https://doi.org/10.1016/j.geomorph.2013.01.019

1241 Vacherat, A., Mouthereau, F., Pik, R., Bellahsen, N., Gautheron, C., Bernet, M., Daudet, M., 1242 Balansa, J., Tibari, B., Jamme, R.P. and Radal, J. 2016. Rift-to-collision transition recorded 1243 by tectonothermal evolution of the northern Pyrenees. Tectonics, 35(4). 1244 https://doi.org/10.1002/2015TC004016

1245 Vanderhaeghe, O. \& Grabkowiak, A. 2014. Tectonic accretion and recycling of the 1246 continental lithosphere during the Alpine orogeny along the Pyrenees. Bulletin de la Société 1247 Géologique de France, 185, 143-155. https://doi.org/ 10.2113/gssgfbull.185.4.257

1248 Vergés, J., Fernàndez, M., Martìnez, A. 2002. The Pyrenean orogen: pre-, syn-, and postcollisional evolution. In: Rosenbaum, G., Lister, G. (Eds.), Reconstruction of the Evolution of the Alpine-Himalayan Orogen, Journal of the Virtual Explorer 8. http://dx.doi.org/10.3809/jvirtex.2002.00058.

1252 Vermeesch, P., Balco, G., Blard, P.-H., Dunai, T.J., Kober, F., Niedermann, S., Shuster, D.L., 1253 Strasky, S., Finlay, F.M., Wieler, R. \& Zimmermann, L. 2012. Interlaboratory comparison of 1254 cosmogenic ${ }^{21} \mathrm{Ne}$ in quartz. Quaternary Geochronology, 26, 20-28, 1255 https://doi.org/10.1016/j.quageo.2012.11.009

1256 Whipple, K.X., 2009. The influence of climate on the tectonic evolution of mountain belts. 1257 Nature Geoscience 2, 97-104. https://doi.org/10.1038/ngeo413

1258 Wittmann, H., von Blanckenburg, F., Maurice, L., Guyot, J.-L., Kubik, P.W., 2011. Recycling 1259 of Amazon floodplain sediment quantified by cosmogenic ${ }^{26} \mathrm{Al}$ and ${ }^{10} \mathrm{Be}$. Geology, v.; no.5; p. 1260 467-470. https://doi.org/10.1130/G31829.1 
Zimmermann, L., Avice, G., Blard, P.-H., Marty, B., Füri, E., and Burnard, P.G. Development

1262

1263

1264

1265

1266

1267

1268

1269

1270

1271

1272

1273

1274

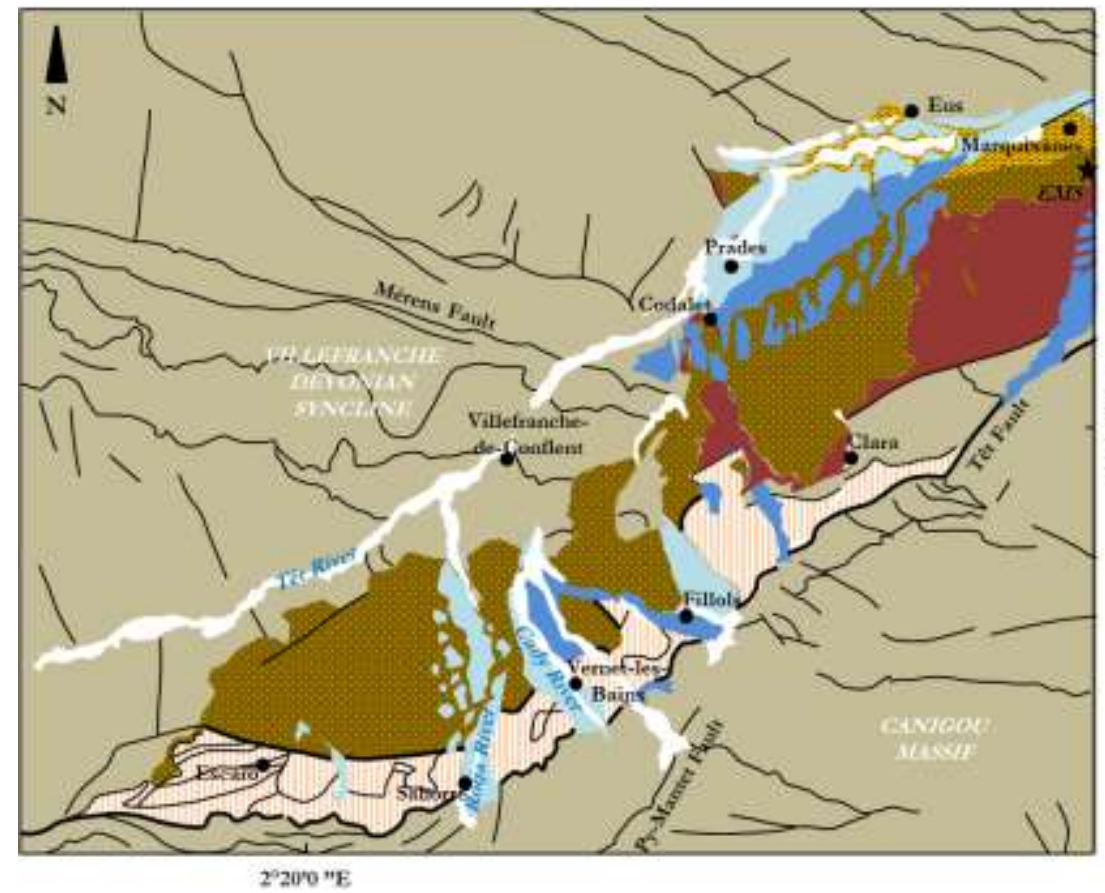

\section{Supplementary information}

\section{Geological and geodynamical contexts}

\section{The Conflent geology}

The Neogene post-alpine tectonics is very marked in the eastern Pyrenees with the formation of Neogene to Quaternary narrow intramontane basins (e.g., Conflent, Serdinya, Capcir) in the Axial Zone. The Conflent basin is delimited by two major N060 ${ }^{\circ}$ to E-W Neogene faults: the Têt - Serdinya fault and its eastern relay the Prades fault. The numerous tectonic markers are often hidden under the Neogene Conflent sedimentary filling.

1275 Figure 1: Geological sketch map of the Northwestern Conflent Basin (according to BRGM

1276 data). This map details the various Neogene formations present in the study area. It is 1277 possible to distinguish: the Escaro and Lentilla formations with the Espira micromammalian 1278 site (EMS) of Lower Burdigalian age (Baudelot and Crouzel, 1974), the Codalet Formation of 1279 Aquitanian to Lower Burdigalian age, the Marquixanes Formation of Aquitanian age. Fault1280 related formations, including gneiss and micaschist olistoliths, are also present. Finally, 1281 Quaternary formations are represented, without the different levels of terraces being 1282 distinguished in this version. 
The base of the filling sequence is dated from the Early Miocene (23-20 Ma), the 200-

1284

1285

1286

1287

1288

1289

1290

1291

1292

1293

1294

1295

1296

1297

1298

1299

1300

1301

1302

1303

1304

1305

1306

1307

1308

1309

1310

1311

1312

1313

1314

1315

1316

1317

$500 \mathrm{~m}$ thick Marquixanes Formation consisting of arkosic sandstone and granite boulders.

The Lentilla Formation, which overcomes it, has a minimum thickness of 200-400 m. It is composed of fluviatile facies whose clasts come from the crystalline massifs of Canigou, Carança and Mont-Louis. Remains of small mammals dated at $20 \mathrm{Ma}$ (Baudelot et Crouzel, 1974) were found at the base of the formation. The Lentilla Formation laterally shifts in facies to the Codalet Formation which sometimes stratigraphically replaces the Marquixanes Formation. The Codalet Formation is characterized by its reddish color as well as the presence of numerous schistous clasts. Moving westward upstream, the Codalet and Lentilla formations laterally shift to the Escaro Formation, a $900 \mathrm{~m}$ thick sequence constituted by massive torrential debris. Finally, large olistoliths border the Canigou massif and are intercalated in the Escaro Formation. This chronology, although generally accepted, is not unanimous (e.g., Clauzon et al., 2015 and references therein).

\section{Pyrenean highly elevated low-relief surfaces}

High-elevation, low-relief surfaces in mountain belts are interpreted as either remnants of post-tectonic peneplains, which are then used to quantify the uplift of the Earth's surface, or remnants of peneplains that developed at high elevation because of a progressive rise of the efficient base level of the drainage system that hampered erosion during the mountain belt building. These two hypotheses were confronted by Bosch et al. (2016), who proposed that the elevation of the chain is isostatically compensated at the lithospheric level. The first hypothesis implying a 2,000-m post-tectonic uprising since the Upper Miocene, these authors favored the hypothesis of a development of the mid-Miocene Pyrenean peneplain at high elevation.

Highly elevated low-relief surfaces (HELR; Babault et al., 2005, Calvet and Gunnell, 2008 and references therein for sources of debate), whose ridges reach altitudes as high as $\sim 2800 \mathrm{~m}$ and whose slopes do not exceed $20^{\circ}$, truncate the Paleozoic units of the Pyrenean range's axial zone and the Mesozoic cover. These surfaces carrying Upper Miocene sediments in discordance $(11.1-8.7 \mathrm{Ma})$ should therefore be anterior to this period.

The origin of these perched surfaces remains enigmatic. It has been proposed that following an episode of peneplenation, a post-orogenic Pliocene uplift phase would have occurred. According to De Sitter (1952), this uplift phase would have resulted from tangential compressive movements that led to crustal thickening of at least $12 \mathrm{~km}$. However, such movements are not documented. According to Brunet (1986), this phase would have resulted from the disappearance of all or a portion of the crustal root during the Neogene. However, geophysical studies (e.g., Chevrot et al., 2014) revealed the presence of a deep root. Thus, 
other hypotheses have been developed over the last ten years. Babault et al. (2005) proposed that the HELRs formed at high elevation because of the substantial filling of the foreland basins by the orogen denudation products, which penetrate in discordance back to the chain interior. This scenario involves a general increase in the base level hampering the erosive capacity of the drainage system, as corroborated by analogue modeling (e.g., Babault et al., 2005). However, this hypothesis has been challenged (e.g., Gunnell and Calvet, 2006; Sinclair et al., 2009). Based on geological, thermochronological or geomorphological data, these authors argue that: (i) surface discrimination would be in dispute; (ii) the erosion surfaces would be staggered and at least multiple, with the lowest level at relatively low altitudes and covering large areas and the highest at altitudes between 2700 and 2900 m; (iii) extrapolating the basin fill model is complex; and (iv) the model assumes significant slopes to connect flattened surfaces and clastic sequences of the piedmont. For these last authors, the heavy and dense lithospheric root that was created during the Pyrenean subduction gradually warmed up and disappeared to the east. The vanishing of this thick root of low-density crust that was edified by the Pyrenean tectonics would have then caused a post-orogenic rebound since 10 Ma that led to the current relief. These assumptions regarding the deep structure of the chain have recently been refuted by the acquisition of new data in the framework of national programs (ANR PYROPE, ANR Pyramid). Recent work that considered these data (Bosch et al., 2016) has suggested that the current elevation of the chain is isostatically compensated at the lithospheric level, which contradicts a 2000-m Upper Miocene to Plio-Quaternary uplift of the Pyrenees and implies that peneplains should have developed during the mid-Miocene at high elevation. Thus, uplift knowledge, if any, in this section of the Pyrenees would provide crucial constraints regarding these still-debated hypotheses.

\section{References}

Babault, J., van den Driessche, J., Bonnet, S., 2005. Origin of the highly elevated Pyrenean peneplain. Tectonics, 24, TC2010. https://doi.org/10.1029/2004TC001697

1346 Baudelot, S., Crouzel, F. 1974. La faune burdigalienne des gisements d'Espira-du-Conflent 1347 (Pyrénées-Orientales). Bull. Soc. Hist. Nat. Toulouse, 110(3-4), 311-326.

1348 Bosch, G.V., Van Den Driessche, J., Babault, J., Robert, A., Carballo, A., Le Carlier, C., 1349 Loget, N., Prognon, C., Wyns, R. and Baudin, T. 2016. Peneplanation and lithosphere 1350 dynamics in the Pyrenees. Comptes Rendus Geoscience, 348, 194-202. 1351 https://doi.org/10.1016/j.crte.2015.08.005 
1352 Brunet, M.F. 1986. The influence of the evolution of Pyrenees on adjacent basins.

1353 Tectonophysics, 129, 343-354. https://doi.org/10.1016/0040-1951(86)90260-X

1354 Calvet M., Gunnell Y. 2008. Planar landforms as markers of denudation chronology: an 1355 inversion of East Pyrenean tectonics based on landscape and sedimentary basin analysis. In:

1356 Gallagher K., Jones S.J., Wainwright J. (eds), Landscape Evolution: Denudation, Climate 1357 and Tectonics Over Different Time and Space Scales, Geological Society, London, Special 1358 Publications, 296, 147-166. https://doi.org/10.1144/SP296.10

1359 Chevrot, S., Villaseñor, A. et Sylvander, M. 2014. High resolution imaging of the Pyrenees 1360 and Massif Central from the data of the PYROPE and IBERARRAY portable array 1361 deployments. Journal of Geophysical Research, 119(8), 6399-6420. https://doi.org/ $136210.1002 / 2014 J B 010953$

1363 Clauzon, G., Le Strat, P., Duvail, C., Do Couto, D., Suc, J.-P., Molliex, S., Bache, F., Besson, 1364 D., Lindsay, E.H., Opdyke, N.D., Rubino, J.-P., Speranta-Maria Popescu, S.-P., Haq, B.U. 1365 and Gorini, C. 2015. The Roussillon Basin (S. France): A case-study to distinguish local and 1366 regional events between 6 and 3 Ma. Marine and Petroleum Geology, 66, 18-40. 1367 https://doi.org/10.1016/j.marpetgeo.2015.03.012

1368 De Sitter, L.U. 1952. Pliocene uplift of Tertiary mountain chains. American Journal of 1369 Science, 250, 297-307. https://doi.org/10.2475/ajs.250.4.297

1370 Gunnell, Y. and Calvet, M. 2006. Comment on «Origin of the highly elevated Pyrenean 1371 peneplain $»$ by J. Babault et al. Tectonics, 25, TC3003.

1372 https://doi.org/10.1029/2004TC001697

1373 Sinclair, H.D., Gibson, M., Lynn, G., and Stuart, F.M. 2009. The evidence for a Pyrenean

1374 Resurrection: a response to Babault et al. (2008). Basin Research, 21, 143-145. 1375 https://doi.org/10.1111/j.1365-2117.2008.00391.x 